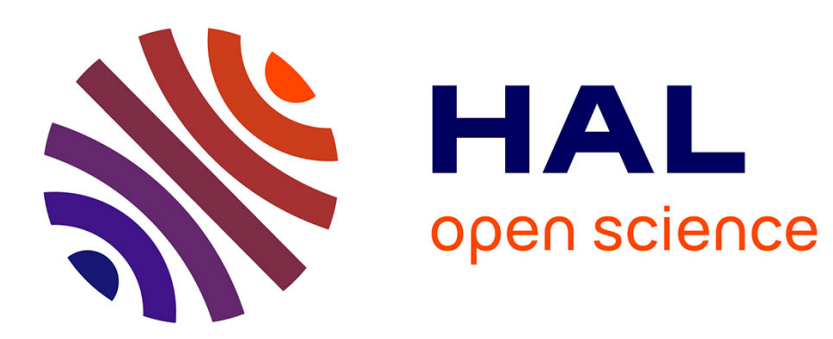

\title{
Statins inhibit aminoglycoside accumulation and cytotoxicity to renal proximal tubule cells
}

Daniel J. Antoine, Abhishek Srivastava, Munir Pirmohamed, B. Kevin Park

\section{To cite this version:}

Daniel J. Antoine, Abhishek Srivastava, Munir Pirmohamed, B. Kevin Park. Statins inhibit aminoglycoside accumulation and cytotoxicity to renal proximal tubule cells. Biochemical Pharmacology, 2009, 79 (4), pp.647. 10.1016/j.bcp.2009.09.021 . hal-00544818

\section{HAL Id: hal-00544818 \\ https://hal.science/hal-00544818}

Submitted on 9 Dec 2010

HAL is a multi-disciplinary open access archive for the deposit and dissemination of scientific research documents, whether they are published or not. The documents may come from teaching and research institutions in France or abroad, or from public or private research centers.
L'archive ouverte pluridisciplinaire HAL, est destinée au dépôt et à la diffusion de documents scientifiques de niveau recherche, publiés ou non, émanant des établissements d'enseignement et de recherche français ou étrangers, des laboratoires publics ou privés. 


\section{Accepted Manuscript}

Title: Statins inhibit aminoglycoside accumulation and cytotoxicity to renal proximal tubule cells

Authors: Daniel J. Antoine, Abhishek Srivastava, Munir Pirmohamed, B. Kevin Park

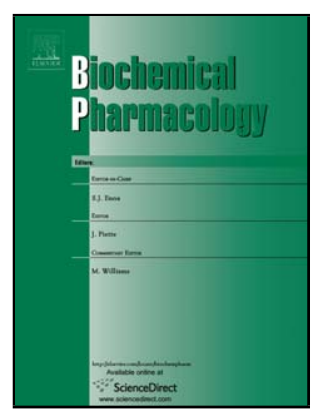

PII:

S0006-2952(09)00800-4

DOI:

doi:10.1016/j.bcp.2009.09.021

Reference:

BCP 10337

To appear in: $\quad B C P$

Received date: $\quad 25-8-2009$

Revised date: 16-9-2009

Accepted date: $\quad$ 17-9-2009

Please cite this article as: Antoine DJ, Srivastava A, Pirmohamed M, Park BK, Statins inhibit aminoglycoside accumulation and cytotoxicity to renal proximal tubule cells, Biochemical Pharmacology (2008), doi:10.1016/j.bcp.2009.09.021

This is a PDF file of an unedited manuscript that has been accepted for publication. As a service to our customers we are providing this early version of the manuscript. The manuscript will undergo copyediting, typesetting, and review of the resulting proof before it is published in its final form. Please note that during the production process errors may be discovered which could affect the content, and all legal disclaimers that apply to the journal pertain. 


\section{TITLE PAGE}

Statins inhibit aminoglycoside accumulation and cytotoxicity to renal proximal tubule cells

Daniel J. Antoine, Abhishek Srivastava, Munir Pirmohamed \& B. Kevin Park

\section{AUTHOR AFFILIATION}

MRC Centre for Drug Safety Science, Department of Pharmacology \& Therapeutics, University of Liverpool, Merseyside, UK

\section{CORRESPONDING AUTHOR}

Dr D.J Antoine

MRC Centre for Drug Safety Science

The Department of Pharmacology \& Therapeutics

University of Liverpool, UK

L69 3GE

Tel: +44 1517950382 .

E-mail: d.antoine@liv.ac.uk

\section{ABBREVIATIONS}


AG, aminoglycoside; HMG-CoA 3-hydroxy-3-methylglutaryl-CoA; IC 50 , half-maximal inhibitory concentration; LC-MS/MS, liquid chromatography tandem mass-spectrometry; LC-MS/MRM, liquid chromatography-mass spectrometry / multiple reaction monitoring; LDH, lactate dehydrogenase; OAT, organic anion transporter; OK, opossum kidney

\section{KEY WORDS}

Gentamicin; HMG-CoA reductase; Mevalonate; Megalin; Nephrotoxicity 


\section{ABSTRACT}

Nephrotoxicity due to renal proximal tubule accumulation of aminoglycoside (AG) antibiotics, such as gentamicin, represents a major clinical problem. Receptor-mediated endocytosis via the multi-ligand receptor megalin is thought to be a key mechanism in the cellular uptake of AGs and nephrotoxicity. This process can be modulated by the intracellular concentration of isoprenoid pyrophosphates derived from the processing of mevalonate by 3 hydroxy-3-methylglutaryl-CoA (HMG-CoA) reductase. Post-translation modifications by isoprenoid pyrophosphates are necessary for GTP-binding protein function. Given that statins inhibit HMG-CoA reductase and therefore affect the concentration of isoprenoid pyrophosphates, we have tested the hypothesis that statins will lead to a reduction in AG renal proximal tubule accumulation and cytotoxicity. Gentamicin accumulated within cultured proximal tubule derived opossum kidney (OK) cells and led to dose- and timedependent cell death which was inhibited by non-toxic doses of simvastatin $\left(\mathrm{IC}_{50} 1.3 \mu \mathrm{M}\right)$, rosuvastatin $\left(\mathrm{IC}_{50} 16.3 \mu \mathrm{M}\right)$ and pravastatin $\left(\mathrm{IC}_{50} 38.8 \mu \mathrm{M}\right)$. The mechanism of inhibition was linked to the degree of cholesterol synthesis inhibition and GTP-binding protein unprenylation. Moreover, co-incubation with mevalonate or geranyl-geranyl pyrophosphate, products of HMG-CoA reductase, reversed the inhibitory effect of statins on cellular accumulation and cytotoxicity of gentamicin. In summary, our data suggest that the inhibition of the mevalonate pathway by statins may provide a potential therapeutic strategy to prevent AG-induced nephrotoxicity. 


\section{INTRODUCTION}

Aminoglycosides (AG), including gentamicin, are a widely prescribed and effective class of antibiotic which have low rates of resistance. They are used in the treatment of a number of severe bacterial infections including those affecting the lungs, heart, biliary and urinary tracts [1]. However, nephrotoxicity represents a serious clinical problem in $10-15 \%$ of patients and is the dose limiting factor for their therapeutic use $[2,3]$. To uncover mechanisms of AGinduced nephrotoxicity would thus be important to improve the therapeutic index and may also allow the development of novel intervention strategies. However, currently apart from once daily dosing [4], no other clinically effective strategies exist for the prevention of AG nephrotoxicity.

Following systemic administration, AGs remain relatively unchanged and have low tissue absorption and plasma protein binding. Around $80 \%$ of the systemic dose is excreted into the urine within $24 \mathrm{~h}$ by glomerular filtration. However, accumulation within the renal cortex, especially in the proximal tubule epithelial cells, remains high compared to other organs (5$10 \%$ dose) [5]. This is thought to be important in the pathogenesis of nephrotoxicity, and thus attention has focused on the molecular and biochemical mechanisms underpinning AG accumulation. This may be key to developing potential strategies for the intervention of toxicity.

Binding of AGs to the multi-ligand receptor, megalin, and cellular uptake by receptormediated endocytosis has been demonstrated to be the principal pathway for accumulation [6]. The abundant negative charges on the extracellular receptor domain facilitate interactions between polybasic substances such as AGs [6]. Indeed, the rank order of AG toxicity 
Megalin also constitutes the main endocytic pathway for the clearance of low molecular weight proteins from the glomerular filtrate, such as albumin, $\beta 2$-microglobulin, transthyretin, vitamin D-binding protein and retinol binding protein [7-10]. Because megalin is highly expressed in the renal cortex, it has been postulated to be a key factor in the organ specific uptake, accumulation and resulting toxicity of AGs [11]. In accordance with this, megalin knock-out mice are protected from the renal accumulation of AGs [12]. Furthermore, protein and peptide ligands which compete with AGs for binding to megalin are effective in reducing AG accumulation in cell lines expressing megalin and the appearance of urinary biomarkers of AG-induced tubular damage in vivo [13].

Several stable proximal tubule cell lines such as those derived from the opossum kidney (OK) can be utilised to study receptor-mediated endocytosis via megalin $[14,15]$. This process requires active GTP-binding proteins [16]. To function correctly, GTP-binding proteins require post-translational prenylation to anchor them and assist their translocation to cellular membranes. Isoprenoid pyrophosphates such as geranyl-geranyl pyrophosphate (GGPP) and farnesyl pyrophosphate (FPP) are mevalonate-derived intermediates formed during the biosynthesis of cholesterol which are used for the modification of GTP-binding proteins [17]. Statins are inhibitors of the enzyme 3-hydroxy-3-methylglutaryl CoA (HMG-CoA) reductase. They are relatively safe and are widely prescribed for the treatment of hyperlipidemia. They inhibit the rate limiting step in the sterol biochemical pathway, the conversion of HMG-CoA to mevalonate [18]. Therefore, by decreasing the intracellular sterol pool, statins can also indirectly inhibit receptor-mediated endocytosis by blocking the post-translational 
modification of GTP-binding proteins [19]. Indeed, statins can inhibit receptor-mediated endocytosis of proteins in vitro [20] by a mechanism which correlates with the inhibition of cholesterol synthesis and an increase in the intracellular level of unprenylated GTP-binding proteins [21]. Since statins have a relatively safe clinical profile, they represent a possible strategy for the prevention of nephrotoxicity in man through the blockade of AG uptake and accumulation. Statins can also prevent other forms of renal injury through their inhibition of protein prenylation [22]. In this in vitro study, we have therefore tested the hypothesis that through the pharmacological inhibition of HMG-CoA reductase, statins can inhibit the receptor-mediated endocytosis of AGs into cultured renal proximal tubule cells and the resultant cytotoxicity. 


\section{MATERIALS AND METHODS}

OK cells were purchased from the European Collection of Cell Cultures (ECACC). Cell culture reagents and test reagents (gentamicin, simvastatin, pravastatin, mevalonolactone, cholesterol and $\left[2-\mathrm{C}^{14}\right]$ acetate were purchased from Sigma-Aldrich (Poole, UK). Rosuvastatin was purchased from Bosche Scientific (NJ, USA). For western blotting, the NuPAGE SDS-PAGE gels were obtained from Invitrogen life sciences (Paisley, UK), the ECL-Plus and hyperfilm from Amersham biosciences (Buckinghamshire, UK) and the antibodies (total and prenylated Rap1A and anti-rabbit actin) from Santa Cruz (CA, USA). All solvent were of high grade HPLC quality from Fischer scientific (Loughborough, UK). Lactate dehydrogenase assay kit was purchased from Roche diagnostics (West Sussex, UK).

\subsection{Cell culture treatment and cytotoxicity assessment}

OK cells were used between passages $40-55$ and seeded at a density of $2 \times 10^{4}$ cells $/ \mathrm{cm}^{2}$ in cell culture plates containing trans-well membrane inserts to promote polarity and megalin expression. Cells were cultured until confluent prior to dosing and maintained in DMEMHam's F-12 mix containing 10\% FBS, 2mmol/L L-glutamine, 100U/ml penicillin and $100 \mu \mathrm{g} / \mathrm{ml}$ streptomycin in a humidified atmosphere $\left(5 \% \mathrm{CO}^{2}, 37^{\circ} \mathrm{C}\right)$. Dosing solutions were prepared in serum free media (mevalonate, gentamicin, GGPP) and as concentrated stock solutions in DMSO (pravastatin, rosuvastatin, simvastatin, GGTI-2147) or ethanol (cholesterol). Control cells were treated with $0.1 \%$ DMSO in serum free media. Cells were dosed in serum free media for up to $48 \mathrm{~h}$ and media containing $1 \%$ serum for later time points. 
Gentamicin-induced cytotoxicity was determined by quantification of lactate dehydrogenase (LDH) release according to the manufacturer's instructions.

\subsection{Gentamicin intracellular quantification by LC-MS/MS}

Remaining cells were washed twice with ice cold PBS, lysed with RIPA buffer and kept on ice for $15 \mathrm{~min}$. A portion was removed for protein content determination by the methods of Bradford et al [23] and samples were centrifuged at $4^{\circ} \mathrm{C}$ for $5 \mathrm{~min}$ at $14,000 \mathrm{rpm}$. Intracellular gentamicin was detected by LC-MS/MS in multiple-reaction monitoring mode (MRM) with the main working parameters and product ion scanning based on methods described previously [24]. Analyses were performed using an Applied Biosystems/MDS Sciex API2000 mass spectrometer with TurboIonSpray source (Applied Biosystems/MDS Sciex, Foster City, CA). Analytes were resolved on a Gemini-NX 5 $\mu \mathrm{m}$ C18 110A 250x4.60mm column (phenomenex). Eluate split-flow to the LC-MS interface was $200 \mu 1 / \mathrm{min}$. The following transitions were utilized to selectivity detect gentamicin: $\mathrm{C} 1 \mathrm{~m} / \mathrm{z} 478$ to $\mathrm{m} / \mathrm{z} 322$; $\mathrm{C} 2 / \mathrm{C} 2 \mathrm{a} \mathrm{m} / \mathrm{z} 464.1$ to $\mathrm{m} / \mathrm{z} 322 ; \mathrm{C} 1 \mathrm{a} \mathrm{m} / \mathrm{z} 450$ to $\mathrm{m} / \mathrm{z} 322$. Data were acquired and processed with the Analyst Software (v.1.4; Sciex). Gentamicin levels were calculated by comparison with a standard curve and normalised to total cellular protein content of remaining cells. Coefficient of variation calculated from 5 standard curves ran on 5 separate days was $<10 \%$ for each data point.

\subsection{Cholesterol synthesis determination}

Cells were incubated with test reagents for $24 \mathrm{~h}$ and $10 \mu \mathrm{Ci}\left[2-\mathrm{C}^{14}\right]$ acetate was added for $5 \mathrm{~h}$. Cells were washed twice with ice cold PBS and lysed in $0.1 \mathrm{M} \mathrm{NaOH}$. Labelled acetate 
incorporation in cholesterol was determined by scintillation counting following HPLC separation as described previously [25]. Percentage (\%) inhibition of cholesterol synthesis was compared to control for test reagents.

\subsection{Western blotting}

OK cells were washed twice with ice cold PBS, lysed in RIPA buffer and incubated on ice for $15 \mathrm{~min}$. Protein concentrations were determined by the Bradford assay [23] and $5 \mu \mathrm{g}$ of the total whole cell lysate was separated by SDS-PAGE. Resolved proteins were transferred to nitrocellulose membranes and probed with antibodies raised against total or unprenylated Rap1A (both $1 / 1000$; overnight) and $\beta$-actin $(1 / 5000 ; 1 \mathrm{~h})$. Secondary antibodies $(1 / 10,000$; 1h) were visualised by exposure to hyperfilm after incubation with ECL-Plus. Unprenylated Rap1A levels were determined by densitometry and normalised to the level of $\beta$-actin.

\subsection{Statistical analysis}

Non-linear regression analysis was used to calculate inhibition constants $\left(\mathrm{IC}_{50}\right)$ from dose response curves recorded at $48 \mathrm{hr}$ post dose and statistical significance was assessed through unpaired t-test analysis, accepting $P<0.05$ as being significant. 


\section{RESULTS}

\subsection{Statins inhibit GTP-binding protein prenylation in OK cells}

Statins can inhibit the function of GTP-binding proteins required for receptor mediated endocytosis of low molecular weight proteins in proximal tubule cells $[17,19,21]$. We therefore explored the relationship between the inhibition of the geranyl-geranylation of a model GTP-binding protein (Rap1A) and the inhibition of gentamicin-induced cytotoxicity. All 3 statins investigated, simvastatin, pravastatin and rosuvastatin, led to a time- and dosedependent increase in the inhibition of Rap1A prenylation as determined by western blotting using an antibody which only recognises unprenylated Rap1A [26] $\left(\mathrm{IC}_{50}\right.$ values given in table 1). Unprenylated Rap1A was absent at baseline, and in the absence of the statins, and furthermore was not induced by gentamicin treatment (Fig.1). The total level of Rap1A remained unchanged with either gentamicin or statin treatment (Fig.1).

\subsection{Statins inhibit gentamicin accumulation and cytotoxicity in $\mathrm{OK}$ cells}

Gentamicin was utilised as a clinically relevant model nephrotoxic aminoglycoside. Gentamicin intra-cellular accumulation was determined by LC-MS/MS (MRM) (Fig.2). Gentamicin had no inhibitory effect on statin pharmacology (i.e., cholesterol synthesis inhibition) or had no inhibitory effect its self on cholesterol synthesis (Fig.3A). Gentamicin accumulated within OK cells in a time-dependent manner which first reached significance at $2 \mathrm{~h}$ post dose. Maximum accumulation was reached $24 \mathrm{~h}$ post dose (Fig.3B). The cytotoxic effect of gentamicin, analysed through LDH leakage, also showed a time dependent pattern (Fig.3C). Cytotoxicity was first significant at time points later than $24 \mathrm{~h}(0.25 \mathrm{mg} / \mathrm{ml})$. There 
was also a direct relationship between gentamicin accumulation and cytotoxicity $\left(\mathrm{R}^{2}=0.85\right)$ observed in OK cells (Fig.3D). Co-administration of simvastatin blocked the intracellular accumulation of gentamicin and its cytotoxicity. Simvastatin alone did not cause a significant increase in the release of $\mathrm{LDH}(11.5 \pm 4.1 \%)$ total amount in culture media) compared to vehicle control levels $(7.5 \pm 2.3 \%)$. This indicates that the inhibitory effect on gentamicin accumulation and cytotoxicity cannot be explained by statin toxicity to the OK cells. This is consistent with literature reports [21]. The effects of pravastatin and rosuvastatin were similar to those of simvastatin. Simvastatin, pravastatin and rosuvastatin were pharmacologically active in OK cells and induced a dose- and time-dependent inhibition of cholesterol synthesis from acetate (Fig.3A and 4A). All statins tested also induced a dose dependent inhibitory effect on the cellular unprenylation of Rap1A, accumulation of gentamicin and resulting cytotoxicity in $\mathrm{OK}$ cells $48 \mathrm{hr}$ after dosing (Fig.4B-D). The $\mathrm{IC}_{50}$ values are given in table 1 for each statin.

\subsection{The relationship between statin-induced HMG-CoA reductase inhibition, Rap1A prenylation and gentamicin accumulation and cytotoxicity}

For simvastatin, pravastatin and rosuvastatin, figure 5A shows the correlation between the inhibition of cholesterol synthesis (surrogate marker for HMG-CoA reductase activity) and gentamicin cellular accumulation. Figure 5B also shows the relationship between the inhibition of cholesterol synthesis by statins and the resulting cytotoxicity induced by gentamicin. An inhibition in cholesterol synthesis of more than $60 \%$ was required to have a significant inhibitory effect on gentamicin accumulation and more than $70 \%$ to have a significant inhibitory effect on cytotoxicity in OK cells. This relationship was also mirrored 
through the correlation between gentamicin accumulation (Fig.5C) and cytotoxicity (Fig.5D) and the degree to which the GTP-binding protein remained unmodified.

\subsection{Addition of isoprenoid products of HMG-CoA reductase reverses the inhibitory effect of statins on gentamicin accumulation and cytotoxicity}

To further define the mechanism of statin inhibition of gentamicin uptake and cytotoxicity and link it to the pharmacological action of the statin, mevalonate, GGPP and cholesterol (downstream products of HMG-CoA reductase) were co-incubated with gentamicin and simvastatin. Only mevalonate and GGPP reversed the inhibitory effect of simvastatin on gentamicin accumulation (Fig.6A), cytotoxicity (Fig.6B) and Rap1A unprenylation (Fig.6C). The level of gentamicin accumulation, cytotoxicity and Rap1A unprenylation was comparable to that seen in cellular incubations where simvastatin was omitted. The effect of mevalonate and GGPP when co-incubated with pravastatin and rosuvastatin was the same as that seen with simvastatin. 


\section{DISCUSSION}

AG-induced nephrotoxicity represents a clinically important adverse drug reaction affecting $10-15 \%$ of patients. The selective uptake and accumulation of AGs into renal proximal tubular cells plays a key role in the development of toxicity $[2,3]$. Schmitz et al demonstrated that megalin-dependent receptor mediated endocytosis is the pathway exclusively responsible for AG renal uptake and accumulation by proximal tubule cells in vivo [12]. Moreover, extracellular peptide competitors of AG/megalin binding also prevent AG uptake in vivo [13]. However, endogenous peptides and proteins are relatively unstable within in vivo systems and may elicit a potentially damaging immune response. Thus, extracellular targeting of megalin with protein and peptide inhibitors cannot be considered as a therapeutic strategy at present and requires further study. Therefore, inhibition of AG uptake with widely used drugs that had a well understood clinical safety profile would represent a potentially important mode of therapeutic intervention for the nephrotoxicity, particularly if it was accompanied by an understanding of the mechanisms responsible for $\mathrm{AG}$ uptake, accumulation and cytotoxicity.

Receptor-mediated endocytosis requires functional GTP-binding proteins which in turn are dependent upon C-terminal post-translational modification derived from products of the mevalonate pathway for correct function and membrane association $[16,17]$. The highly potent statin, rosuvastatin, has been shown to inhibit proximal tubular uptake of low molecular weight proteins without altering renal function by a mechanism linked to the inhibition of receptor-mediated endocytosis [20, 21, 27, 28]. We hypothesised that through the pharmacological inhibition of HMG-CoA reductase, and hence mevalonate production, AG accumulation and cytotoxicity could be inhibited by licensed statins. 
We utilised the in vitro OK cell line derived from the proximal tubule of the American opossum, to investigate the mechanism. OK cells retain megalin-mediated protein binding and uptake, dependent on GTP-protein function, comparable to in vivo situations [14, 15, 29, 30] and have previously been used to investigate AG cytotoxicity [31] and the biochemistry of statin renal transport [32]. We also cultured OK cells on trans-well membrane inserts to promote polarity and megalin expression [33]. Using this model, our data shows that gentamicin (a model nephrotoxic AG) was cytotoxic in vitro in a dose-and time-dependent manner and this was directly proportional to drug accumulation. By $24 \mathrm{hr} 100 \%$ cell death was observed with a gentamicin concentration of $1 \mathrm{mg} / \mathrm{ml}$ which is comparable to literature values seen with gentamicin dosed renal tubular cells [34]. Furthermore, cytotoxicity was inhibited by statins, and this was directly due to the pharmacological action of statins and the degree of GTP-binding protein unprenylation, rather than being a function of the inhibition of AG receptor binding.

Studies in OK cells have shown that statins do not inhibit the cell surface binding of low molecular weight proteins or fluid phase endocytosis of proteins [21]. Trafficking of megalinligand containing vesicles within cells is preceded by the acidification of fused early endosomes with endocytic clathrin-coated vesicles. These early events are directly disrupted by chlorpromazine and cytochalasin D through actions on clathrin and the cytoskeleton [29]. However, statin inhibition of gentamicin uptake was not rapid in this investigation. Instead, as suggested by Sidaway et al., [21] statins caused a gradual depletion or inactivation of the co-factors required for early uptake. A high threshold level in the degree of the inhibition of cholesterol synthesis and unmodification of Rap1A was required to significantly inhibit gentamicin accumulation and toxicity. In addition, the time course for the appearance of the 
surrogate unprenylated GTP-binding protein (Rap1A) mirrored the time course of inhibition of gentamicin toxicity, further supporting our hypothesis that statin treatment results in a gradual depletion of the intracellular isoprenoid pool and progressive inactivation of GTPbinding proteins involved in megalin-mediated AG uptake.

The key finding in this investigation which supports the hypothesis tested was that the protective effect of statins was reversed by mevalonate. Mevalonate is the downstream product of HMG-CoA reductase and a precursor for the necessary isoprenoid products required for GTP-binding protein geranyl-geranylation. Moreover, the reversal of the statin protective effect was also seen with the addition of GGPP, but not with cholesterol (from which GTP-binding protein modifications are not derived). Mevalonate and GGPP modulation further provides strong evidence to link the protective effect of statins on gentamicin cytotoxicity to the inhibition of HMG-CoA reductase and the mevalonate biochemical pathway.

Although the OK cell model represents a suitable in vitro model to investigate receptormediated endocytosis and statin pharmacology, it is possible that the findings seen here, with respect to the effect of statins on the inhibition of gentamicin cytotoxicity, may differ in vivo because of the different pharmacokinetic properties of the statins. It is important to have a comprehensive understanding of the factors that determine the disposition of a drug in vivo when investigating the effect of pharmacodynamically compounds in vitro [21]. For instance, it is possible that lipophilic statins such as simvastatin may not be as effective as hydrophilic statins. Within this in vitro study, the relative potency of each statin in the inhibition of cholesterol synthesis, Rap1A modification and the inhibition of gentamicin cytotoxicity could be ranked in terms of the relative lipophilicity of each statin (simvastatin > rosuvastatin > 
pravastatin) [35]. Simvastatin undergoes greater than $80 \%$ hepatic extraction compared to more hydrophilic statins such as pravastatin which undergo around $45 \%$ hepatic extraction and $80 \%$ renal clearance [36]. Active tubular secretion can account for $40 \%$ of the renal clearance of pravastatin [37, 38]. Rosuvastatin undergoes $28 \%$ renal clearance, of which $90 \%$ can be accounted for by active uptake by proximal tubule cells [39]. For hydrophilic statins, such as pravastatin and rosuvastatin, OATs (organic anion transporters) localised on the basolateral membrane of proximal tubule cells have been shown to play a central role in their renal uptake. However, the expression patterns of the different sub-types of the transporters are also important. For instance, rosuvastatin is a good substrate for OAT3 and not for OAT1 [21], whereas OK cells mainly express OAT1 [32]. It is possible that if the OK cells stably expressed the full complement of transporters observed in vivo, the inhibitory effect of the hydrophilic statins, with respect to inhibition of toxicity, would be more pronounced and the rank order of potency, with respect to inhibition of HMG-CoA reductase, would better reflect that seen clinically.

In man, animal models and the in vitro system investigated here, gentamicin nephrotoxicity is concentration-dependent being related to the degree of drug cellular uptake $[1,12]$. In man and in animal models, gentamicin may take much longer to induce renal damage than that observed in our cell model. Additionally, the optimal concentration required in vivo for efficacy is around 20 times lower than the concentration used in vitro. Thus, one possible refinement of our in vitro model might be to use lower AG concentration over longer time periods [31]. However, it is important to note that (a) although the concentrations we have used are higher than those attained for efficacy, many patients achieve much higher concentrations, which is when they run into problems with nephrotoxicity; and (b) gentamicin toxicity in vivo does not solely depend on the plasma concentration, but more so 
on accumulation of $5-10 \%$ of the dose. Calculations from our in vitro model show that approximately $6.5 \%$ of the dose accumulated prior to the induction of cell death which, taken together with megalin expression and the ability to inhibit cholesterol synthesis, supports the use of this in vitro model as a test of the hypothesis.

The results presented in this investigation provide evidence that through the inhibition of HMG-CoA reductase, statins can inhibit the receptor-mediated endocytosis of AGs into renal proximal tubule cells and the resulting toxicity. This was linked to the depletion of intracellular isoprenoid pyrophosphates derived from mevalonate required for GTP-binding protein prenylation and function. This now needs to be taken further, first of all in an animal model of AG-nephrotoxicity, and secondly in proof of concept studies in patients who receive repeated courses of $\mathrm{AG}$, and therefore are most susceptible to renal damage, such as cystic fibrosis. The main advantage of using this approach is the large amount of knowledge we have gained about the efficacy and safety of statins, and is also consistent with their increasing use and investigation in other non-lipid diseases [40], including in cystic fibrosis to reduce bronchiolar inflammation (http://clinicaltrials.gov/ct2/show/NCT00255242?term=statin+and+cystic+fibrosis\&rank=1).

\section{ACKNOWLEDGMENTS}

This work was supported by the Medical Research Council (grant number G0700654) through the Centre for Drug Safety Science (CDSS). 


\section{REFERENCES}

[1] Tan KH, Mulheran M, Knox AJ, Smyth AR. Aminoglycoside prescribing and surveillance in cystic fibrosis. Am J Respir Crit Care Med 2003;167:819-23.

[2] Begg EJ, Barclay ML. Aminoglycosides--50 years on. British Journal of Clinical Pharmacology 1995;39:597-603.

[3] Slaughter RL, Cappelletty DM. Economic impact of aminoglycoside toxicity and its prevention through therapeutic drug monitoring. Pharmacoeconomics 1998;14:38594.

[4] Smyth A, Walters S. Prophylactic antibiotics for cystic fibrosis.[update of Cochrane Database Syst Rev. 2001;(3):CD001912; PMID: 11687002]. Cochrane Database Syst Rev 2003:CD001912.

[5] Mathews A, Bailie GR. Clinical pharmacokinetics, toxicity and cost effectiveness analysis of aminoglycosides and aminoglycoside dosing services. J Clin Pharm Ther $1987 ; 12: 273-91$.

[6] Moestrup SK, Cui S, Vorum H, Bregengard C, Bjorn SE, Norris K, et al. Evidence that epithelial glycoprotein 330/megalin mediates uptake of polybasic drugs.[see comment]. Journal of Clinical Investigation 1995;96:1404-13.

[7] Christensen EI, Moskaug JO, Vorum H, Jacobsen C, Gundersen TE, Nykjaer A, et al. Evidence for an essential role of megalin in transepithelial transport of retinol. J Am Soc Nephrol 1999;10:685-95.

[8] Nykjaer A, Dragun D, Walther D, Vorum H, Jacobsen C, Herz J, et al. An endocytic pathway essential for renal uptake and activation of the steroid 25-(OH) vitamin D3. Cell 1999;96:507-15. 
[9] Orlando RA, Rader K, Authier F, Yamazaki H, Posner BI, Bergeron JJ, et al. Megalin is an endocytic receptor for insulin. J Am Soc Nephrol 1998;9:1759-66.

[10] Sousa MM, Norden AG, Jacobsen C, Willnow TE, Christensen EI, Thakker RV, et al. Evidence for the role of megalin in renal uptake of transthyretin. Journal of Biological Chemistry 2000;275:38176-81.

[11] Nagai J, Tanaka H, Nakanishi N, Murakami T, Takano M. Role of megalin in renal handling of aminoglycosides. Am J Physiol Renal Physiol 2001;281:F337-44.

[12] Schmitz C, Hilpert J, Jacobsen C, Boensch C, Christensen EI, Luft FC, et al. Megalin deficiency offers protection from renal aminoglycoside accumulation. Journal of Biological Chemistry 2002;277:618-22.

[13] Watanabe A, Nagai J, Adachi Y, Katsube T, Kitahara Y, Murakami T, et al. Targeted prevention of renal accumulation and toxicity of gentamicin by aminoglycoside binding receptor antagonists. J Controlled Release 2004;95:423-33.

[14] Brunskill NJ, Cockcroft N, Nahorski S, Walls J. Albumin endocytosis is regulated by heterotrimeric GTP-binding protein G alpha i-3 in opossum kidney cells. American Journal of Physiology 1996;271:F356-64.

[15] Malstrom K, Stange G, Murer H. Identification of proximal tubular transport functions in the established kidney cell line, OK. Biochim Biophys Acta 1987;902:269-77.

[16] Clague MJ. Molecular aspects of the endocytic pathway. Biochemical Journal 1998;336:271-82.

[17] Magee T, Marshall C. New insights into the interaction of Ras with the plasma membrane. Cell 1999;98:9-12.

[18] Goldstein JL, Brown MS. Regulation of the mevalonate pathway. Nature $1990 ; 343: 425-30$. 
[19] Cordle A, Koenigsknecht-Talboo J, Wilkinson B, Limpert A, Landreth G. Mechanisms of statin-mediated inhibition of small G-protein function. Journal of Biological Chemistry 2005;280:34202-9.

[20] Verhulst A, D'Haese PC, De Broe ME. Inhibitors of HMG-CoA reductase reduce receptor-mediated endocytosis in human kidney proximal tubular cells. J Am Soc Nephrol 2004;15:2249-57.

[21] Sidaway JE, Davidson RG, McTaggart F, Orton TC, Scott RC, Smith GJ, et al. Inhibitors of 3-hydroxy-3-methylglutaryl-CoA reductase reduce receptor-mediated endocytosis in opossum kidney cells. J Am Soc Nephrol 2004;15:2258-65.

[22] Khwaja A, O'Connolly J, Hendry BM. Prenylation inhibitors in renal disease. Lancet 2000;355:741-4.

[23] Bradford MM. A rapid and sensitive method for the quantitation of microgram quantities of protein utilizing the principle of protein-dye binding. Analytical Biochemistry 1976;72:248-54.

[24] Heller DN, Peggins JO, Nochetto CB, Smith ML, Chiesa OA, Moulton K. LC/MS/MS measurement of gentamicin in bovine plasma, urine, milk, and biopsy samples taken from kidneys of standing animals. J Chromatogr B Analyt Technol Biomed Life Sci 2005;821:22-30.

[25] McTaggart F, Brown GR, Davidson RG, Freeman S, Holdgate GA, Mallion KB, et al. Inhibition of squalene synthase of rat liver by novel 3' substituted quinuclidines. Biochemical Pharmacology 1996;51:1477-87.

[26] Staal A, Frith JC, French MH, Swartz J, Gungor T, Harrity TW, et al. The ability of statins to inhibit bone resorption is directly related to their inhibitory effect on HMGCoA reductase activity. J Bone Miner Res 2003;18:88-96. 
[27] Brewer HB, Jr. Benefit-risk assessment of Rosuvastatin 10 to 40 milligrams. Am J Cardiol 2003;92:23K-9K.

[28] Olsson AG, McTaggart F, Raza A. Rosuvastatin: a highly effective new HMG-CoA reductase inhibitor. Cardiovasc Drug Rev 2002;20:303-28.

[29] Gekle M, Mildenberger S, Freudinger R, Schwerdt G, Silbernagl S. Albumin endocytosis in OK cells: dependence on actin and microtubules and regulation by protein kinases. American Journal of Physiology 1997;272:F668-77.

[30] Schwegler JS, Heppelmann B, Mildenberger S, Silbernagl S. Receptor-mediated endocytosis of albumin in cultured opossum kidney cells: a model for proximal tubular protein reabsorption. Pflugers Arch 1991;418:383-92.

[31] Gibbons CE, Maldonado-Perez D, Shah AN, Riccardi D, Ward DT. Calcium-sensing receptor antagonism or lithium treatment ameliorates aminoglycoside-induced cell death in renal epithelial cells. Biochim Biophys Acta 2008;1782:188-95.

[32] Sauvant C, Holzinger H, Gekle M. Modulation of the basolateral and apical step of transepithelial organic anion secretion in proximal tubular opossum kidney cells. Acute effects of epidermal growth factor and mitogen-activated protein kinase. Journal of Biological Chemistry 2001;276:14695 - 703.

[33] Nielsen R, Birn H, Moestrup SK, Nielsen M, Verroust P, Christensen EI. Characterization of a kidney proximal tubule cell line, LLC-PK1, expressing endocytotic active megalin. J Am Soc Nephrol 1998;9:1767-76.

[34] Sandoval RM, Reilly JP, Running W, Campos SB, Santos JR, Phillips CL, et al. A non-nephrotoxic gentamicin congener that retains antimicrobial efficacy. J Am Soc Nephrol 2006;17:2697-705. 
[35] McTaggart F, Buckett L, Davidson R, Holdgate G, McCormick A, Schneck D, et al. Preclinical and clinical pharmacology of Rosuvastatin, a new 3-hydroxy-3methylglutaryl coenzyme A reductase inhibitor. Am J Cardiol 2001;87:28B-32B.

[36] Neuvonen PJ, Backman JT, Niemi M. Pharmacokinetic comparison of the potential over-the-counter statins simvastatin, lovastatin, fluvastatin and pravastatin. Clin Pharmacokinet 2008;47:463-74.

[37] White CM. A review of the pharmacologic and pharmacokinetic aspects of rosuvastatin. J Clin Pharmacol 2002;42:963-70.

[38] Hatanaka T. Clinical pharmacokinetics of pravastatin: mechanisms of pharmacokinetic events. Clin Pharmacokinet 2000;39:397-412.

[39] Martin PD, Warwick MJ, Dane AL, Brindley C, Short T. Absolute oral bioavailability of rosuvastatin in healthy white adult male volunteers. Clinical Therapeutics $2003 ; 25: 2553-63$.

[40] Steffens S, Mach F. Drug insight: Immunomodulatory effects of statins--potential benefits for renal patients? Nature Clinical Practice Nephrology 2006;2:378-87.

\section{CONFLICT OF INTEREST}

The authors wish to report no competing financial interests

\section{FIGURE LEGENDS}

Fig.1. 
Statins inhibit Rap1A prenylation in OK cells. Western blot analysis of the time and dose dependent effect of (A) simvastatin, (B) rosuvastatin and (C) pravastatin on the degree of unprenylated Rap1A in OK cells. OK cells were incubated with gentamicin $(0.25 \mathrm{mg} / \mathrm{ml})$ in the presence and absence of a statin for $24 \mathrm{hr}$. $10 \mu \mathrm{M}$ simvastatin and $30 \mu \mathrm{M}$ of either rosuvastatin or pravastatin was used for the time course analysis. Equal amounts of protein were separated by SDS-PAGE from whole cell RIPA lysates. The presence unprenylated Rap1A was determined by western blot and compared to a $\beta$-actin loading control and the level of total Rap1A protein. Western blots are representative of 3 independent experiments.

Fig.2.

Gentamicin intracellular quantification by LC-MS/MRM. (A) Chemical structure and MS fragmentation of gentamicin components. (B) Individual ion chromatograms of the MRM detection of gentamicin components in OK cells incubated with gentamicin. MRM transitions given on each trace. Intracellular gentamicin was calculated based on the sum of total ion counts from a standard curve.

Fig.3.

Gentamicin is accumulated and causes toxicity to OK cells which can by inhibited by simvastatin. (A) The effect of gentamicin $(0.25 \mathrm{mg} / \mathrm{ml})$, simvastatin $(10 \mu \mathrm{M})$ and simvastatin $(10 \mu \mathrm{M})+$ gentamicin $(0.25 \mathrm{mg} / \mathrm{ml})$ on cholesterol synthesis (inhibition of HMG-CoA reductase) in OK cells over time. The effect on cholesterol synthesis was determined by the addition of $\left[2-\mathrm{C}^{14}\right]$ acetate for the final $5 \mathrm{hr}$ and the inhibitory effect of statins on the incorporation into cholesterol was determined as $\%$ inhibition $24 \mathrm{hr}$ after the statin dose. (B) The effect of simvastatin $(10 \mu \mathrm{M})$ on the time dependent intracellular accumulation of gentamicin $(0.25 \mathrm{mg} / \mathrm{ml})$ in OK cells. (C) The effect of simvastatin $(10 \mu \mathrm{M})$ on the time $(0-$ 
$72 \mathrm{hr}, 0.25 \mathrm{mg} / \mathrm{ml}$ ) dependent cytotoxicity induced by gentamicin in OK cells. Gentamicin accumulation was determined by LC-MS/MRM ( $\mu$ g gentamicin/mg cellular protein) and cytotoxicity was determined by LDH leakage into cell culture media (U/l). (D) The linear relationship between gentamicin accumulation and cytotoxicity in OK cells. Correlation coefficient is given where required ( $\square$; OK cells incubated with $30 \mu \mathrm{M}$ pravastatin and $0.25 \mathrm{mg} / \mathrm{ml}$ gentamicin over $0-72 \mathrm{hr})(\bullet$; OK cells incubated with $10 \mu \mathrm{M}$ simvastatin and $0.25 \mathrm{mg} / \mathrm{ml}$ gentamicin over $0-72 \mathrm{hr}$ ). Data is given as mean $\pm \mathrm{S} . \mathrm{D}$ of 3 independent experiments. Statistical significance was assigned relative to time matched vehicle dosed controls $* p<0.05, * * p<0.01$ or simvastatin + gentamicin compared to gentamicin alone $\dagger p$ $<0.05, \dagger \dagger p<0.01$

Fig.4.

Dose dependent inhibitory effects of statins in OK cells. The dose dependent inhibitory effect of statins in OK cells on (A) cholesterol synthesis, (B) Rap1A unprenylation, (C) gentamicin cellular accumulation and (D) gentamicin-induced cytotoxicity. OK cells were incubated with gentamicin $(0.25 \mathrm{mg} / \mathrm{ml})$ with simvastatin $(\mathrm{O} ; 0-10 \mu \mathrm{M})$, pravastatin $(\square ; 0-100 \mu \mathrm{M})$ or rosuvastatin $(\bullet ; 0-100 \mu \mathrm{M})$ for $48 \mathrm{hr}$. The effect on cholesterol synthesis was determined as in fig.3. Rap1A unprenylation was determined as described in fig.1. Gentamicin cellular accumulation was determined by LC-MS/MRM ( $\mu$ g gentamicin/mg cellular protein) and cytotoxicity was determined by LDH leakage into the cell culture media (U/1). Data is given as mean \pm S.D of 3 independent experiments. Statistical significance was assigned relative to time matched gentamicin $+0 \mu \mathrm{M}$ statin dosed controls $* p<0.05$, ** $p<0.01$ and $* * * p<$ 0.005 .

Fig.5. 
The relationship between statin pharmacology and the protective effect on gentamicin cytotoxicity. The relationship between the statin-induced inhibition of (A) gentamicin accumulation $(\mu \mathrm{g} / \mathrm{mg})$ and (B) gentamicin-induced cytotoxicity (LDH leakage; U/l) in OK cells with the degree of the inhibition of HMG-CoA reductase (\% inhibition of cholesterol synthesis). The relationship between the statin-induced inhibition of (C) gentamicin accumulation $(\mu \mathrm{g} / \mathrm{mg}$ ) and (D) gentamicin-induced cytotoxicity (LDH leakage; U/l) in OK cells with the degree of Rap1A unprenylation. OK cells were incubated with gentamicin $(0.25 \mathrm{mg} / \mathrm{ml})$ and either simvastatin $(\mathrm{O} ; 0-10 \mu \mathrm{M})$, pravastatin $(\square ; 0-100 \mu \mathrm{M})$ or rosuvastatin $(\diamond ; 0-100 \mu \mathrm{M})$ for $48 \mathrm{hr}$. Cholesterol synthesis inhibition, gentamicin accumulation and resulting cytotoxicity were determined as described for fig.3. Rap1A unprenylation was determined by western blot and normalised to $\beta$-actin as described in fig.1. Data is given as mean \pm S.D of 3 independent experiments (horizontal error bars cholesterol synthesis or unprenylation of Rap1A, vertical error bars gentamicin accumulation or cytotoxicity were required).

Fig.6.

Modulation of statin protective effects by isoprenoid pyrophosphates. The effect of mevalonate, geranyl-geranyl pyrophosphate (GGPP) or cholesterol addition on the inhibitory effect of simvastatin on (A) gentamicin cellular accumulation, (B) gentamicin-induced cytotoxicity and (C) Rap1A prenylation in OK cells. Cells were incubated with gentamicin $(0.25 \mathrm{mg} / \mathrm{ml})$ and either a solvent vehicle control $(0.1 \%$ DMSO $)$, mevalonate $(10 \mu \mathrm{M})$, GGPP $(10 \mu \mathrm{M})$ or cholesterol $(100 \mu \mathrm{M})$ for $48 \mathrm{hr}$ with and without simvastatin $(10 \mu \mathrm{M})$. Gentamicin cellular accumulation and resulting cytotoxicity was determined as described in figure 2 . Rap1A unprenylation was determined as described in figure 1. Data is given as mean \pm S.D of 3 independent experiments. Statistical significance was assigned ${ }^{* *} p<0.01$ and $* * * p<$ 
1 


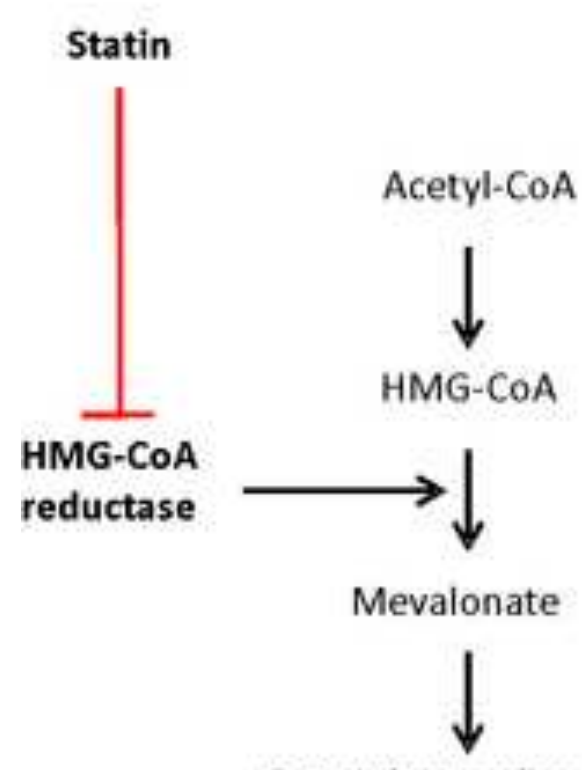

Geranyl-pyrophosphate

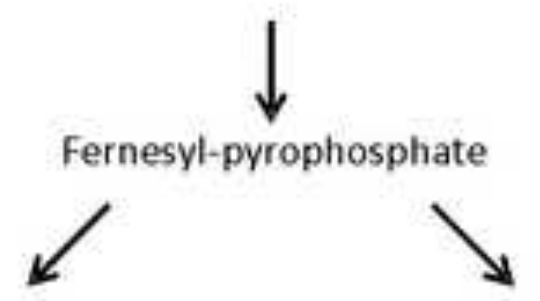

Squalene

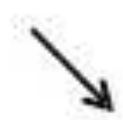

Renal proximal

tubule cell

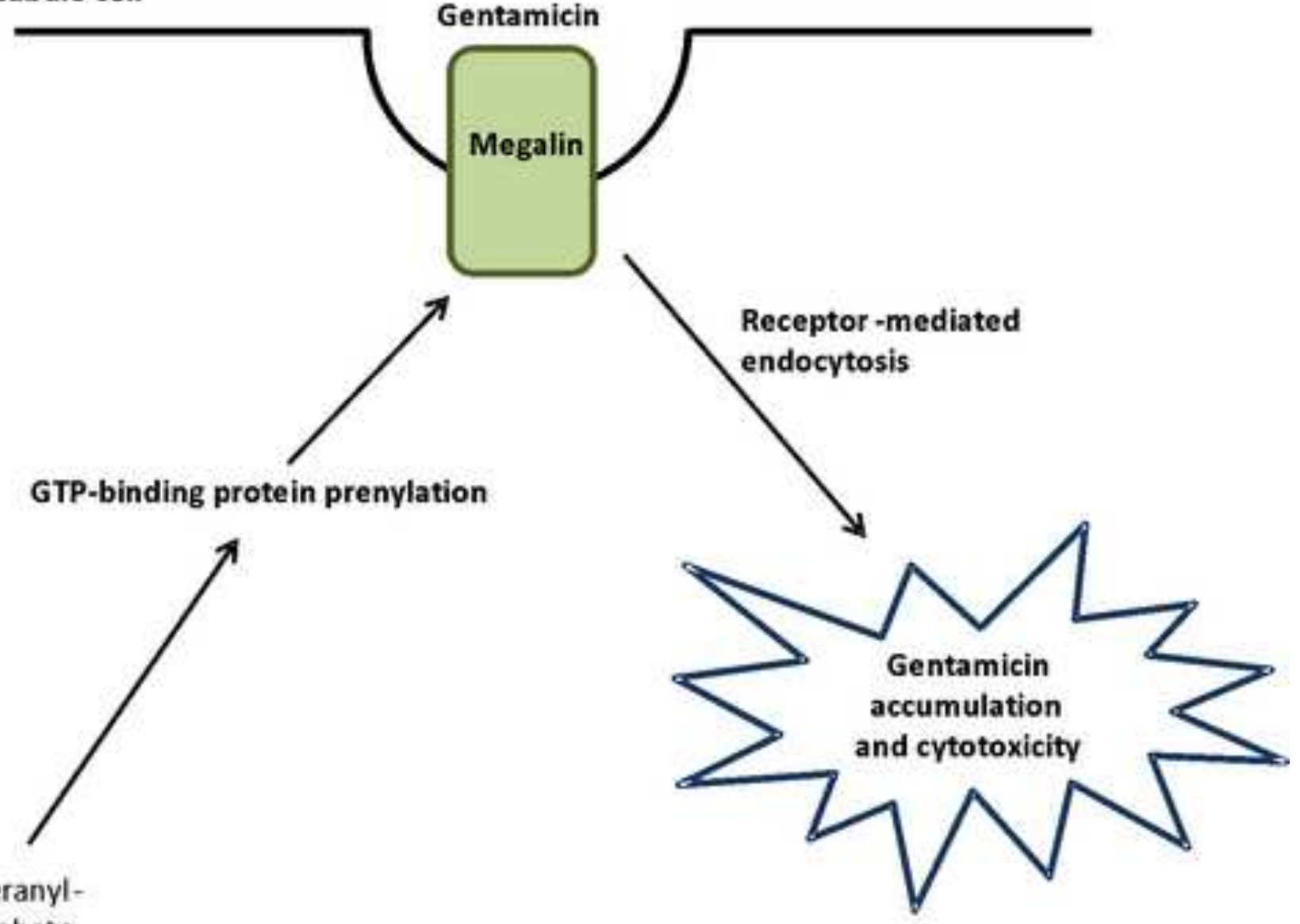

Geranyl-geranyl-

pyrophosphate

Cholesterol 
Table 1.

Comparison of $\mathrm{IC}_{50}$ values for the inhibitory effect of statins on cholesterol synthesis and gentamicin-induced inhibition of Rap1A prenylation, drug accumulation and cytotoxicity in OK cells. Values were obtained from dose-response curves generated for each statin incubated with and without gentamicin for $48 \mathrm{hr}$. Data is given as mean $\mathrm{IC}_{50}$ value $\pm \mathrm{S}$.D of 3 independent experiments.

\section{$\mathrm{IC}_{50}(\mu \mathrm{M})$}

Statin

$\begin{array}{cccc}\text { Cholesterol } & \text { Rap1A } & \text { Gentamicin } & \text { Gentamicin } \\ \text { synthesis } & \text { prenylation } & \text { accumulation } & \text { cytotoxicity }\end{array}$

\begin{tabular}{lcccc}
\hline Simvastatin & $0.01(0.003)$ & $0.05(0.01)$ & $0.50(0.20)$ & $1.30(0.40)$ \\
& & & & \\
\hline Rosuvastatin & $0.08(0.02)$ & $1.70(0.20)$ & $3.40(1.30)$ & $16.30(3.90)$ \\
& & & & \\
\hline Pravastatin & $0.60(0.10)$ & $6.20(1.20)$ & $11.40(4.70)$ & $38.80(6.20)$
\end{tabular}


A

Gentamicin + Simvastatin (Time - h)

Gentamicin + Simvastatin (Statin $-\mu \mathrm{M})$

\begin{tabular}{|llllllll}
0 & 1 & 4 & 8 & 24 & 48 & 72 \\
\hline & & & & & & &
\end{tabular}

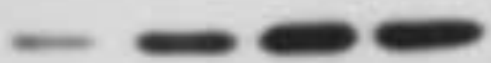

w

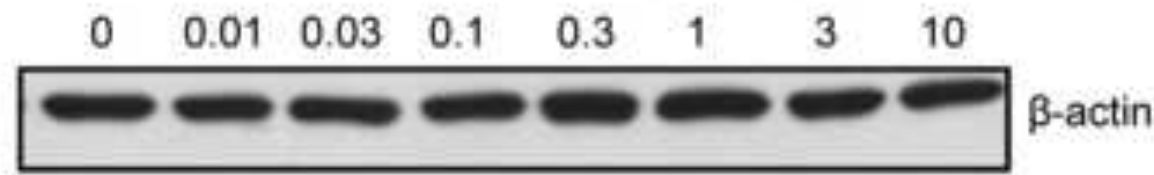

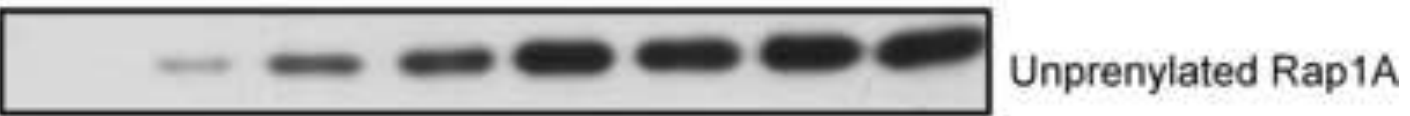

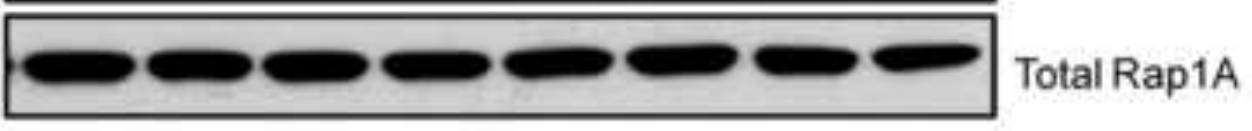

B Gentamicin + Rosuvastatin (Time - h)

Gentamicin + Rosuvastatin (Statin $-\mu \mathrm{M})$

\begin{tabular}{|llllllll}
0 & 1 & 4 & 8 & 24 & 48 & 72 \\
\hline & & & & & & & \\
\hline
\end{tabular}

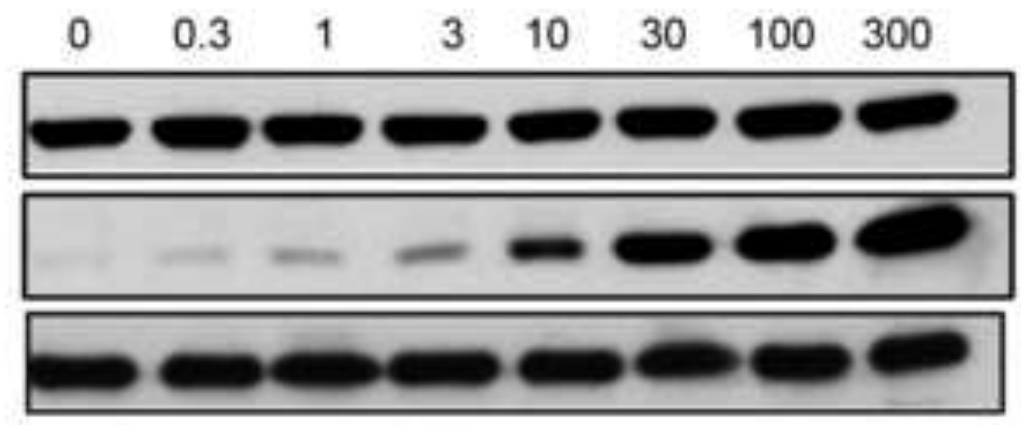

$\beta$-actin

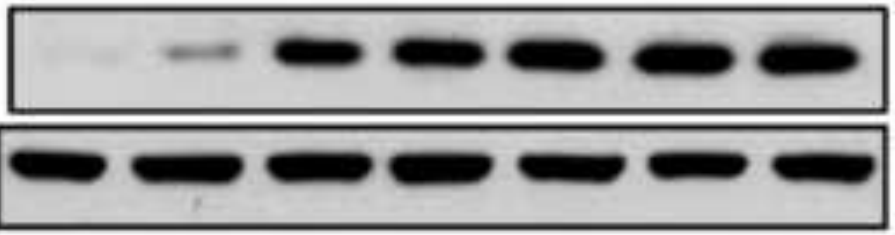

Unprenylated Rap1A

Total Rap1A

C

Gentamicin + Pravastatin (Time - h)

Gentamicin + Pravastatin (Statin - $\mu \mathrm{M})$
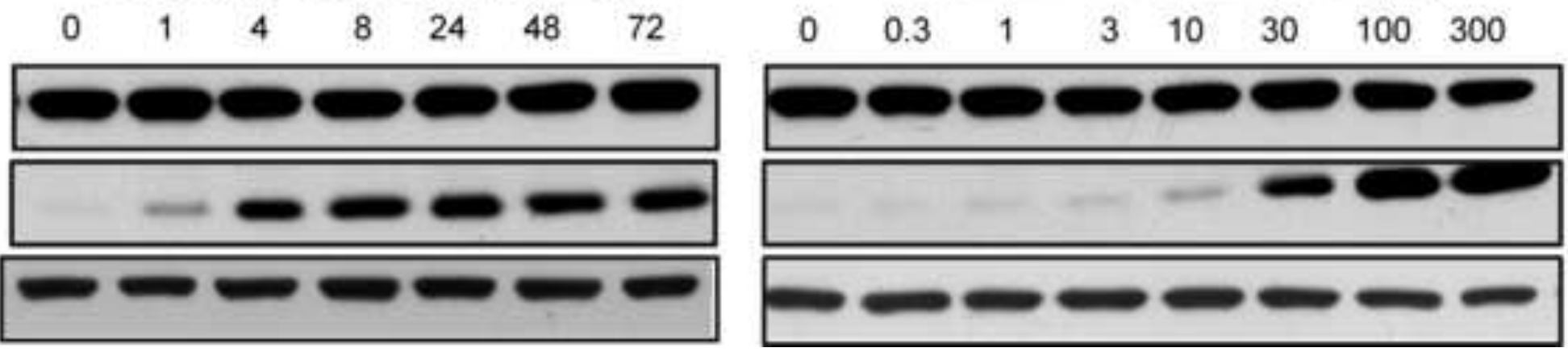

$\beta$-actin

Unprenylated Rap1A

Page 29 of 34 
A

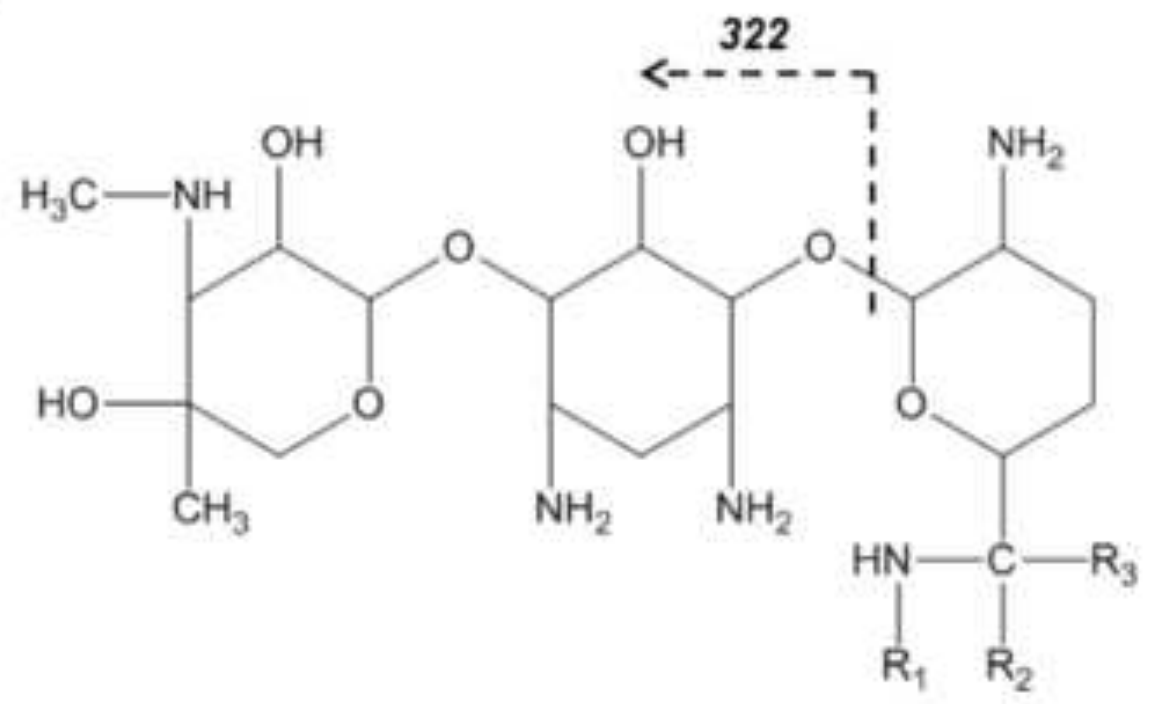

\begin{tabular}{|c|c|c|c|c|}
\hline Component & $\begin{array}{c}\mathbf{m} / \mathbf{z} \text { of } \mathbf{M H} \\
\text { ion }\end{array}$ & $\mathbf{R}_{\mathbf{1}}$ & $\mathbf{R}_{\mathbf{2}}$ & $\mathbf{R}_{3}$ \\
\hline $\mathrm{C} 1 \mathbf{a}$ & 450 & $\mathrm{H}$ & $\mathrm{H}$ & $\mathrm{H}$ \\
\hline $\mathrm{C} 2, \mathrm{C} 2 \mathrm{a}$ & 464 & $\mathrm{H}$ & $\mathrm{CH}_{3}$ & $\mathrm{CH}_{3}$ \\
\hline $\mathrm{C} 1$ & 478 & $\mathrm{CH}_{3}$ & $\mathrm{H}$ & $\mathrm{CH}_{3}$ \\
\hline
\end{tabular}

B

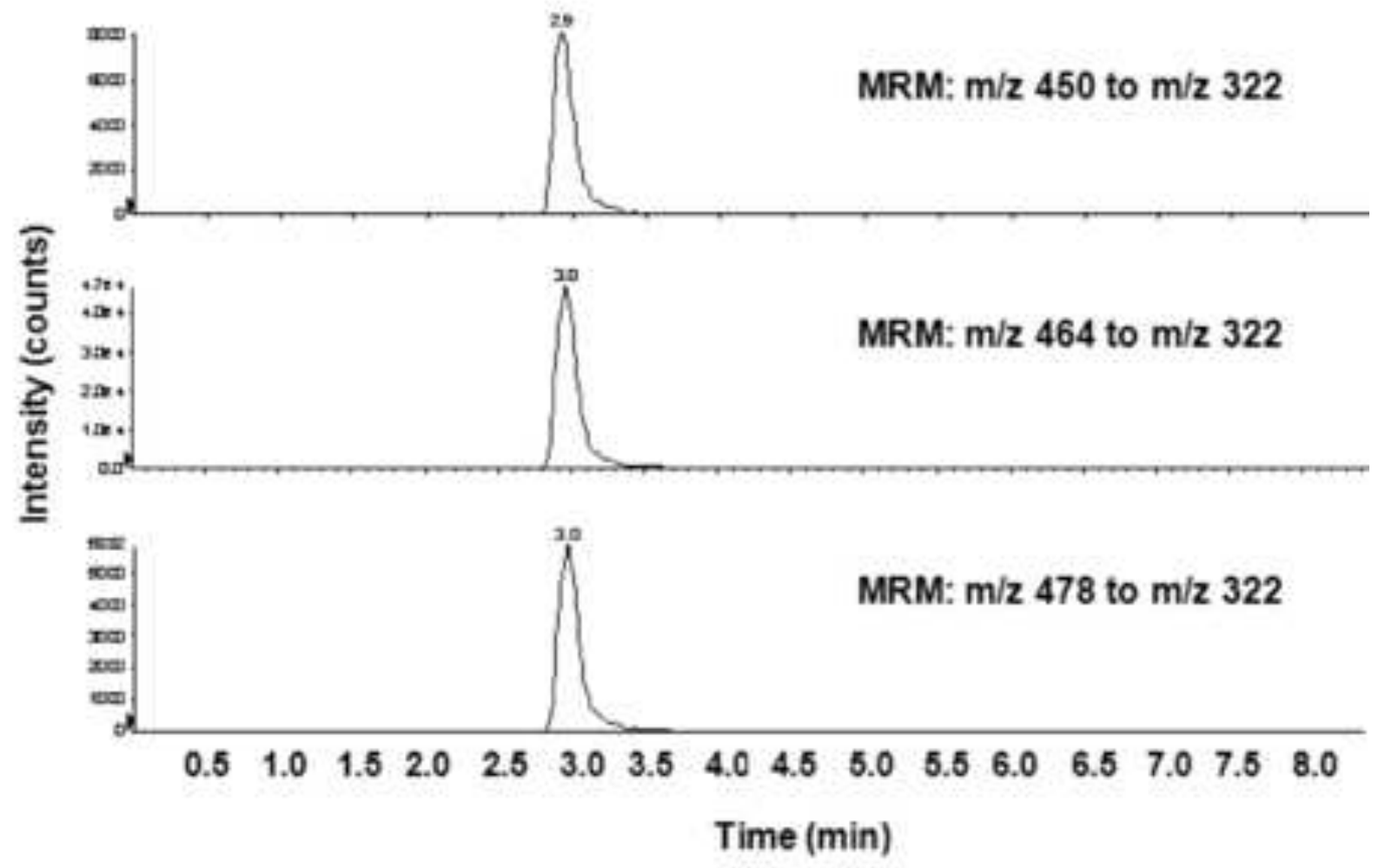


A

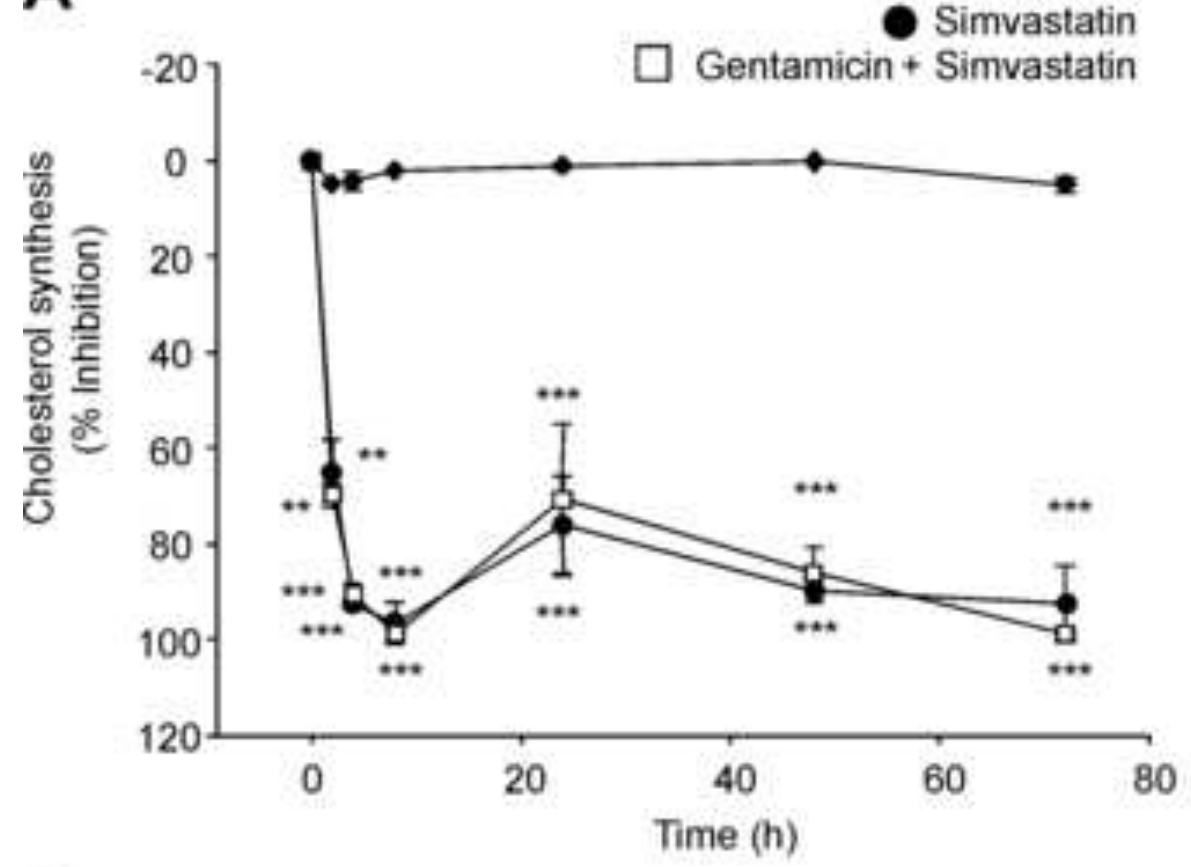

C

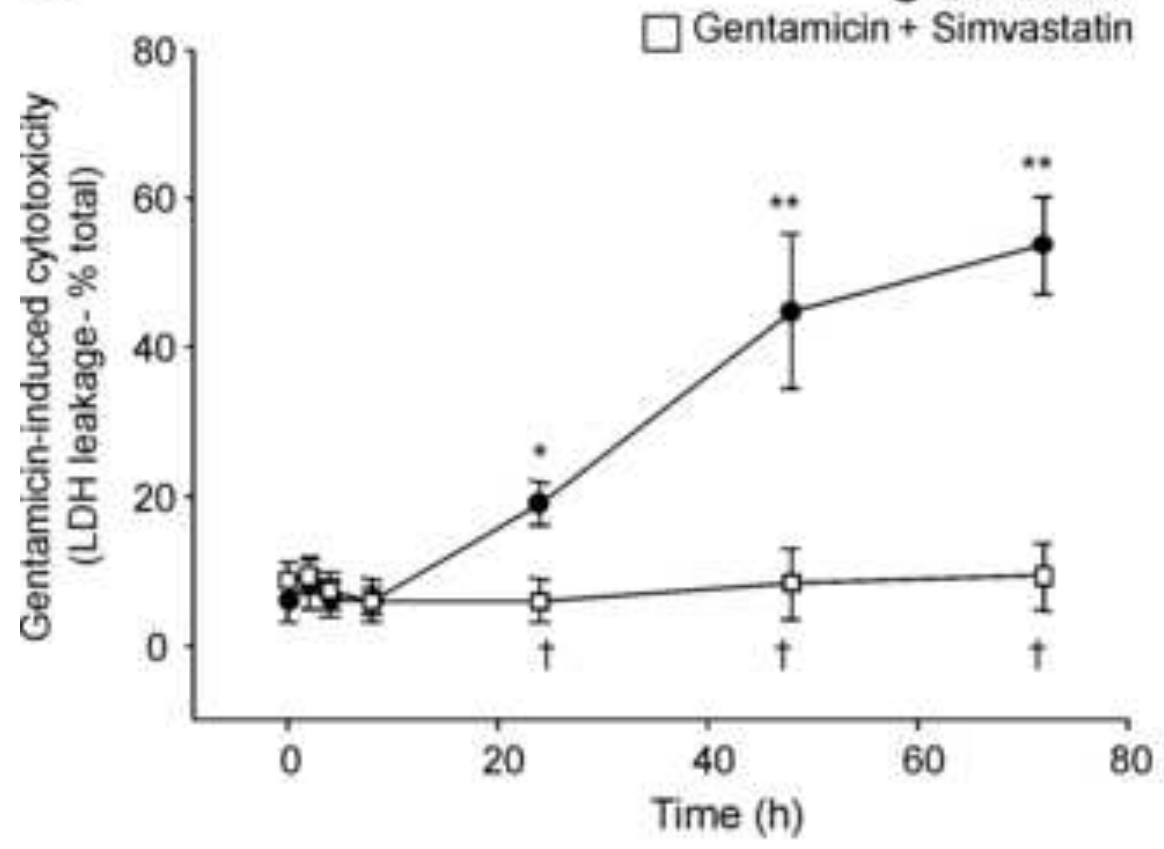

B

Gentamicin

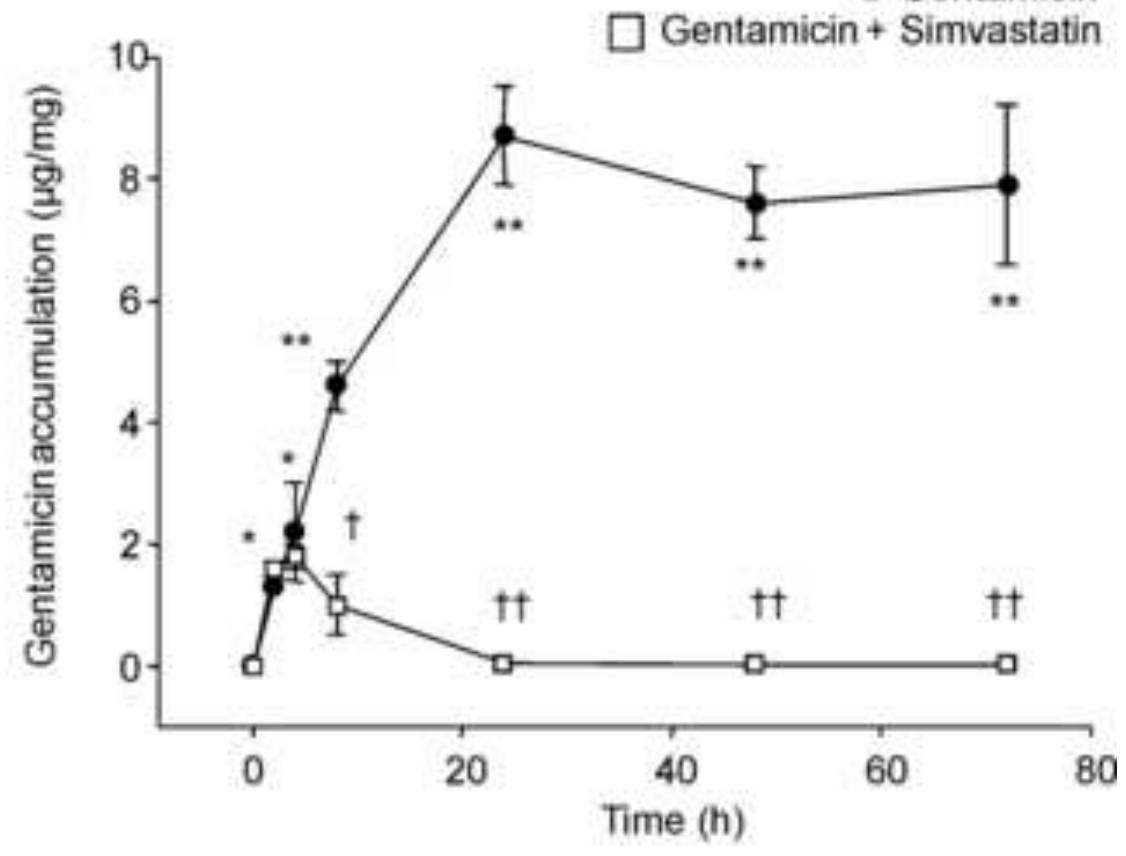

D

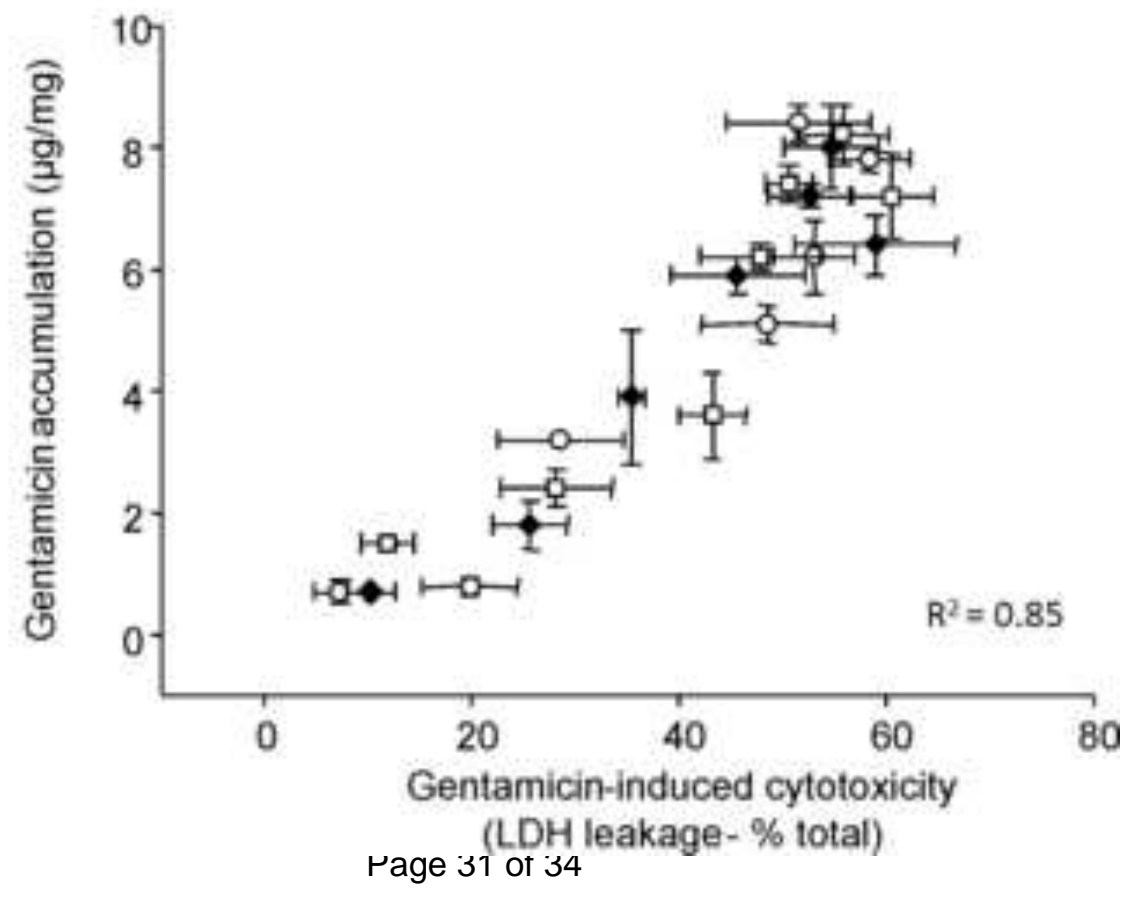


A

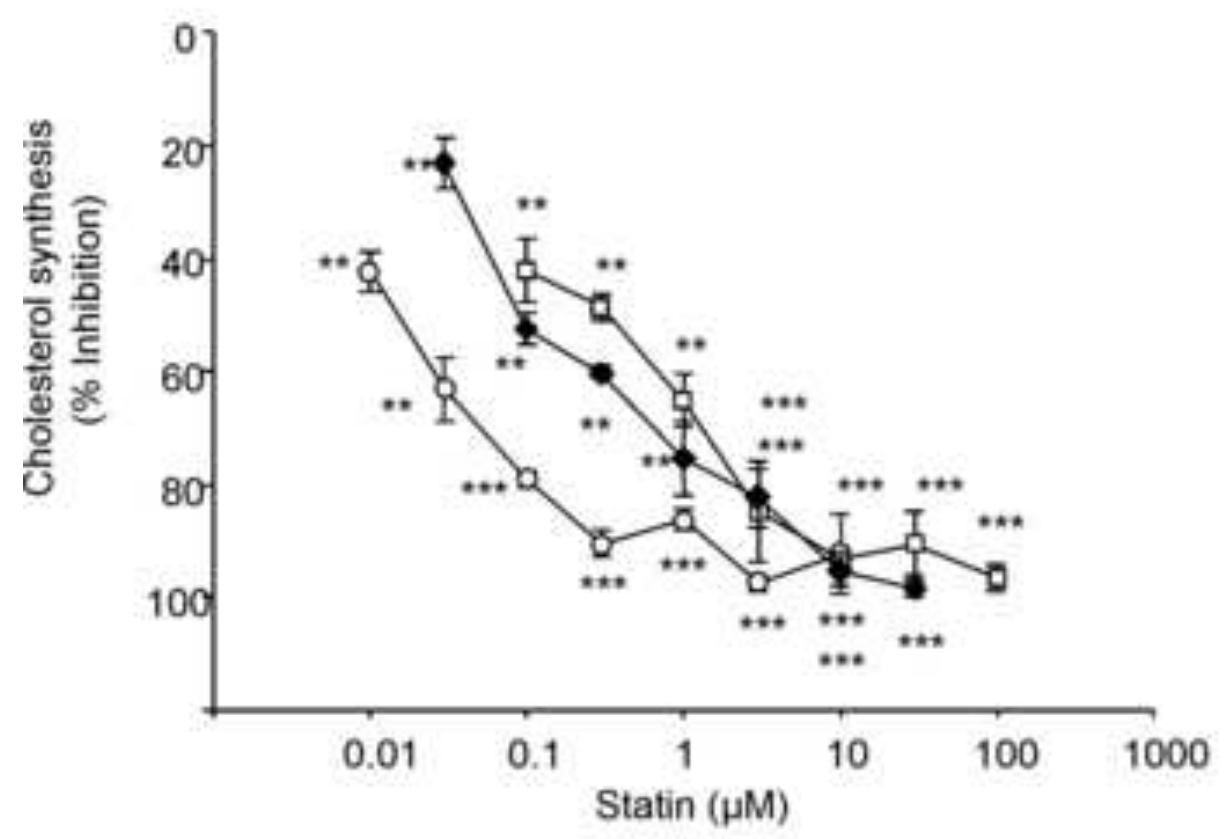

C

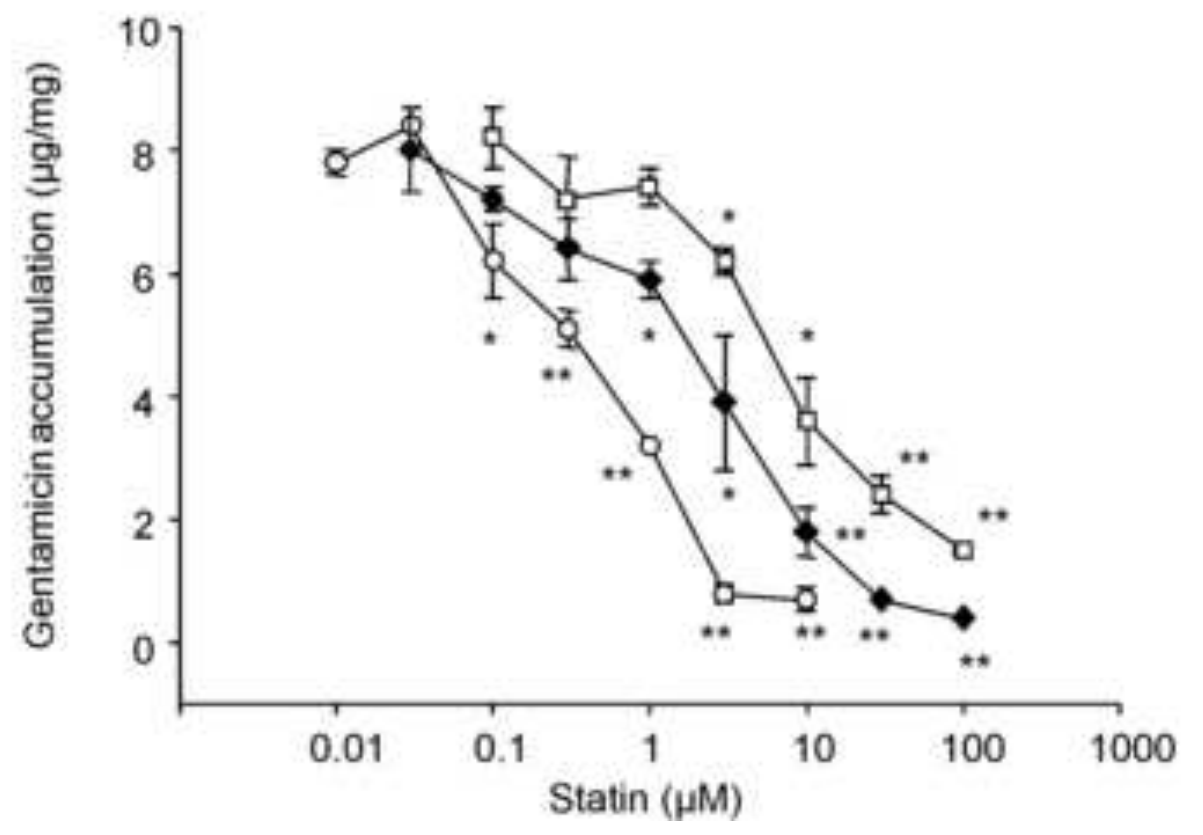

B

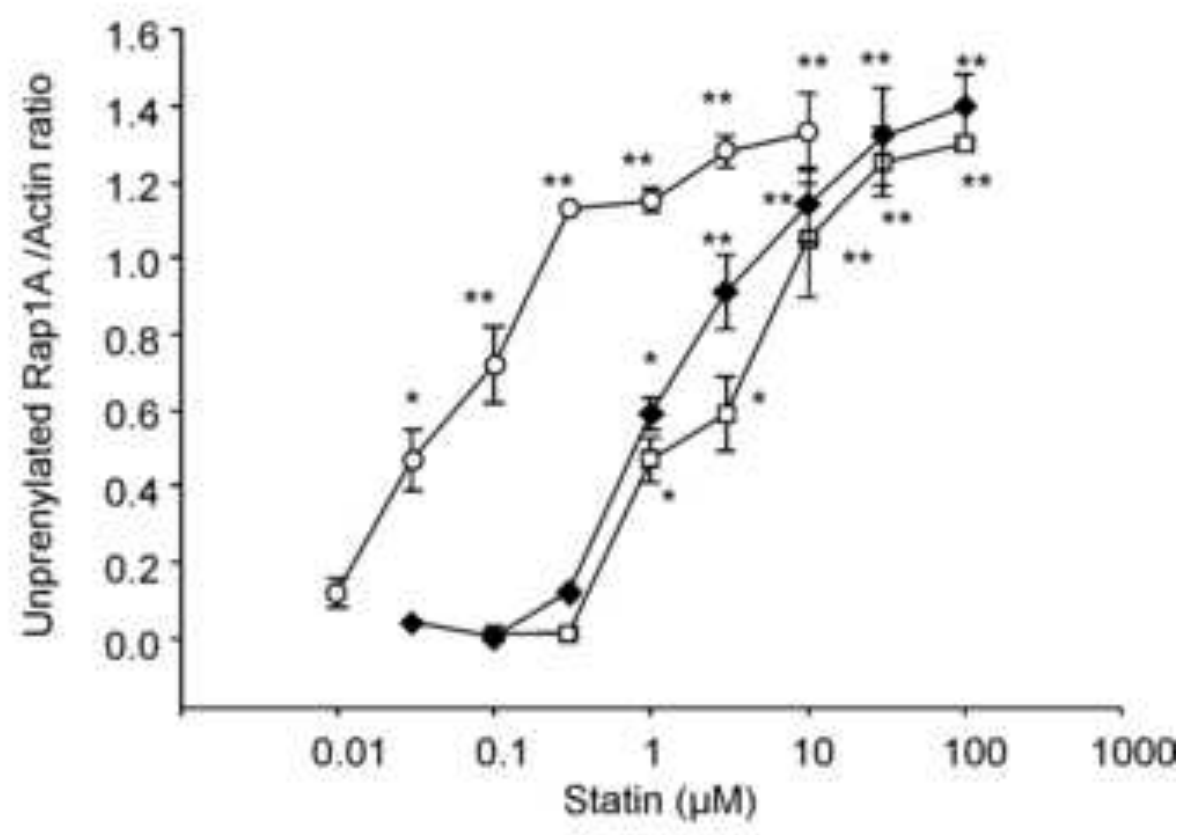

D

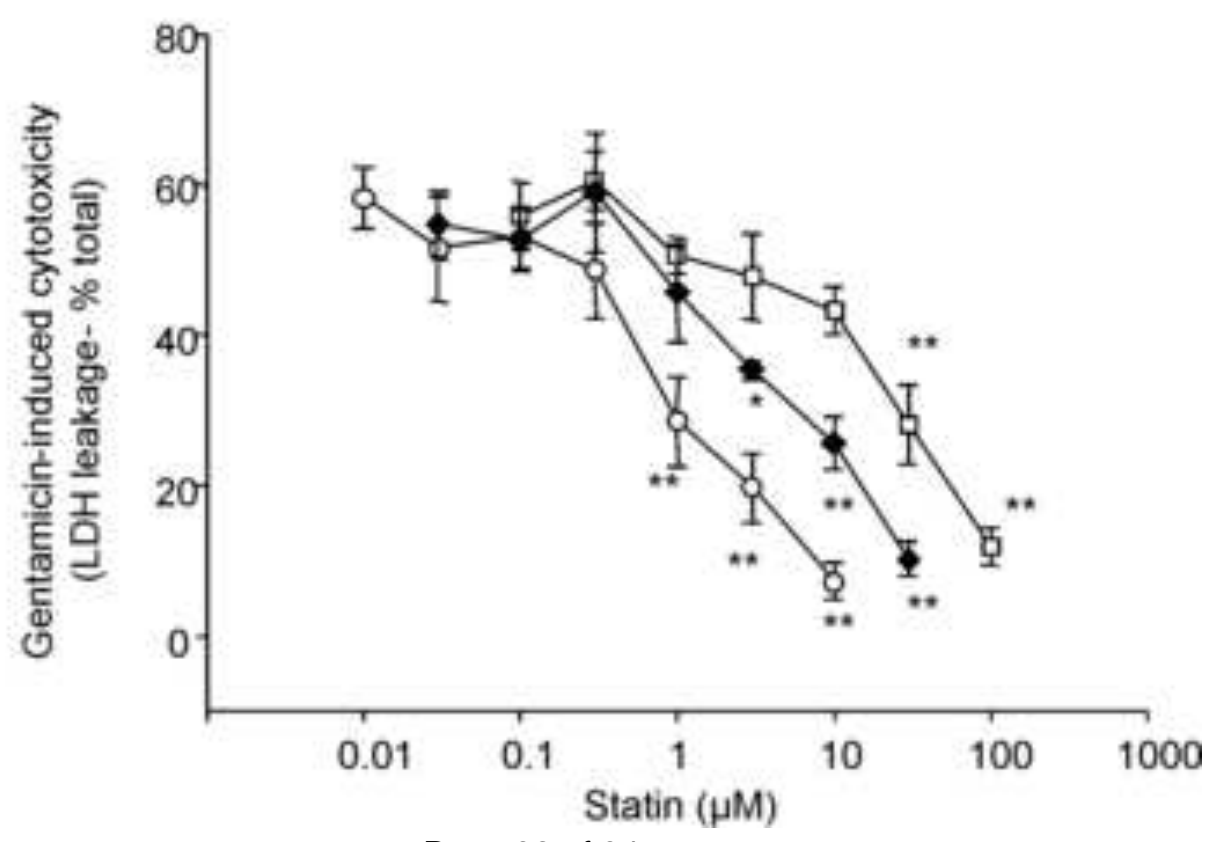

Page 32 of 34 
A

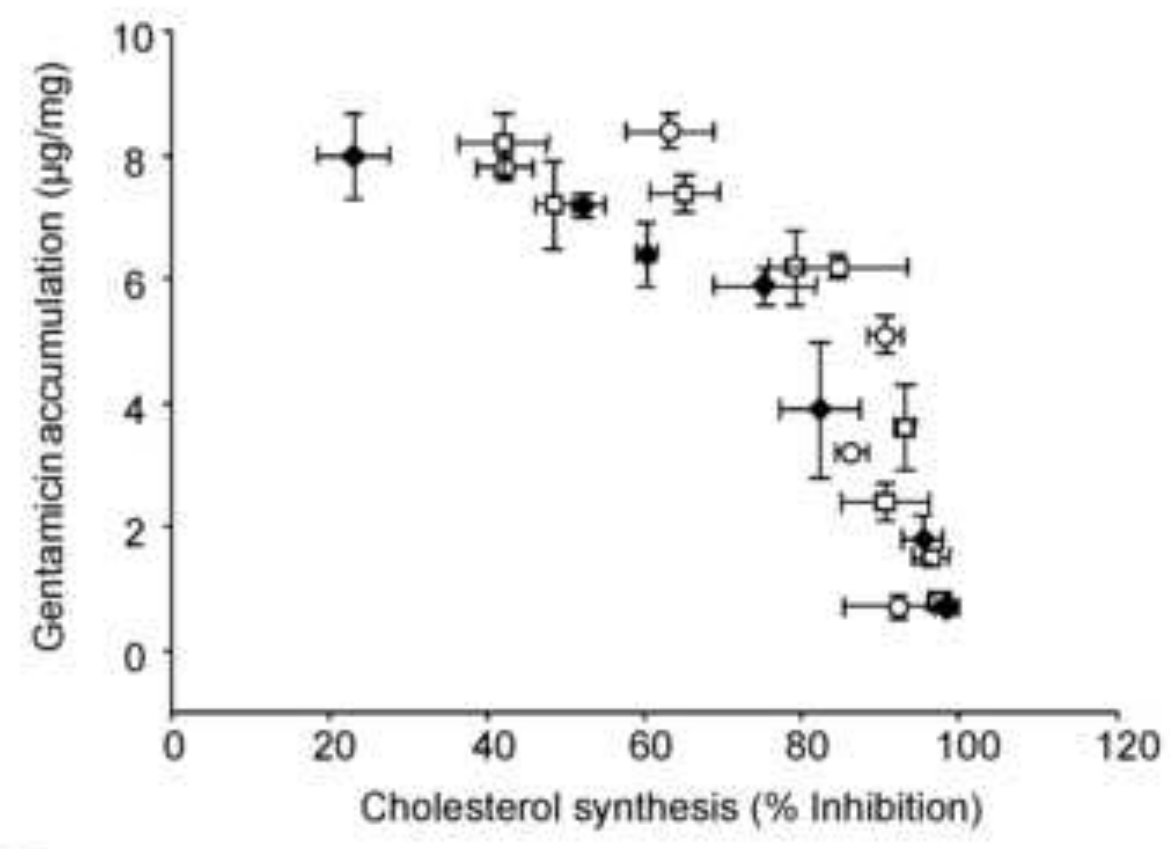

C

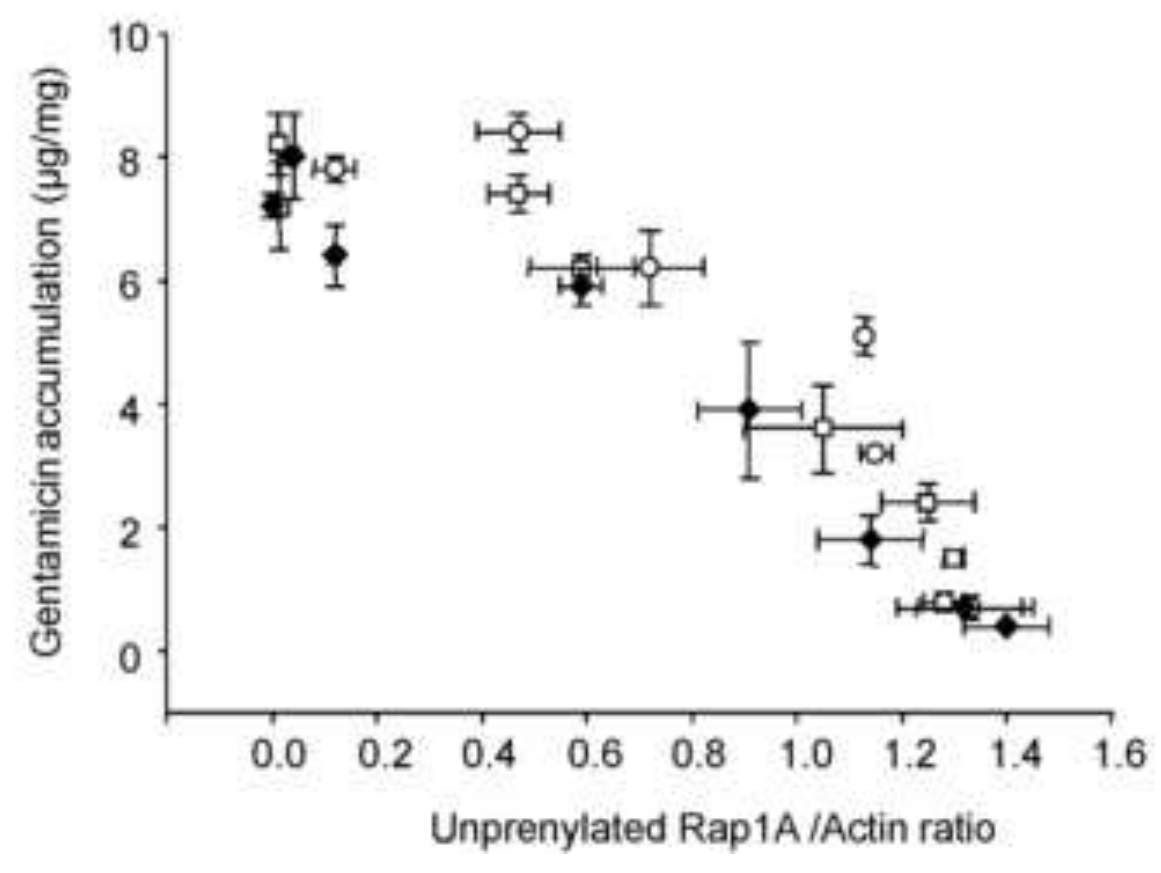

B

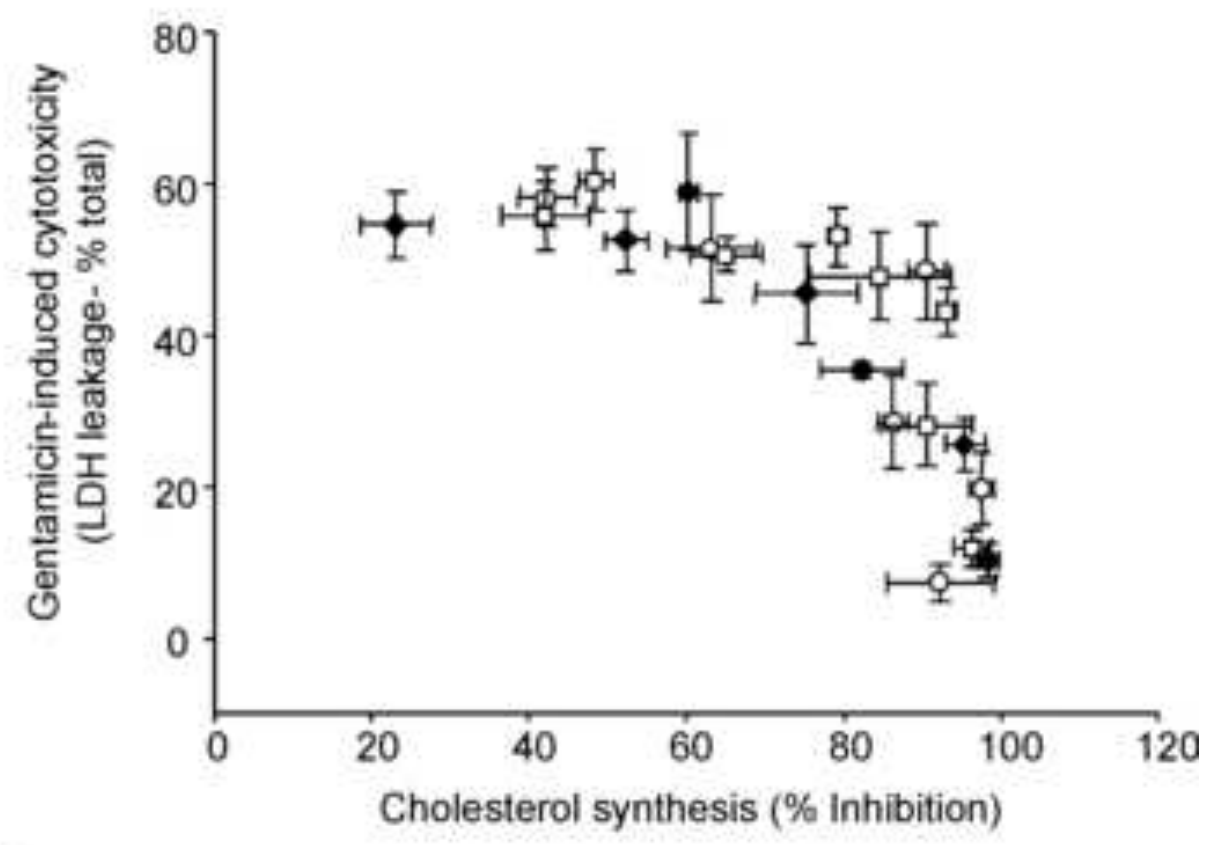

D

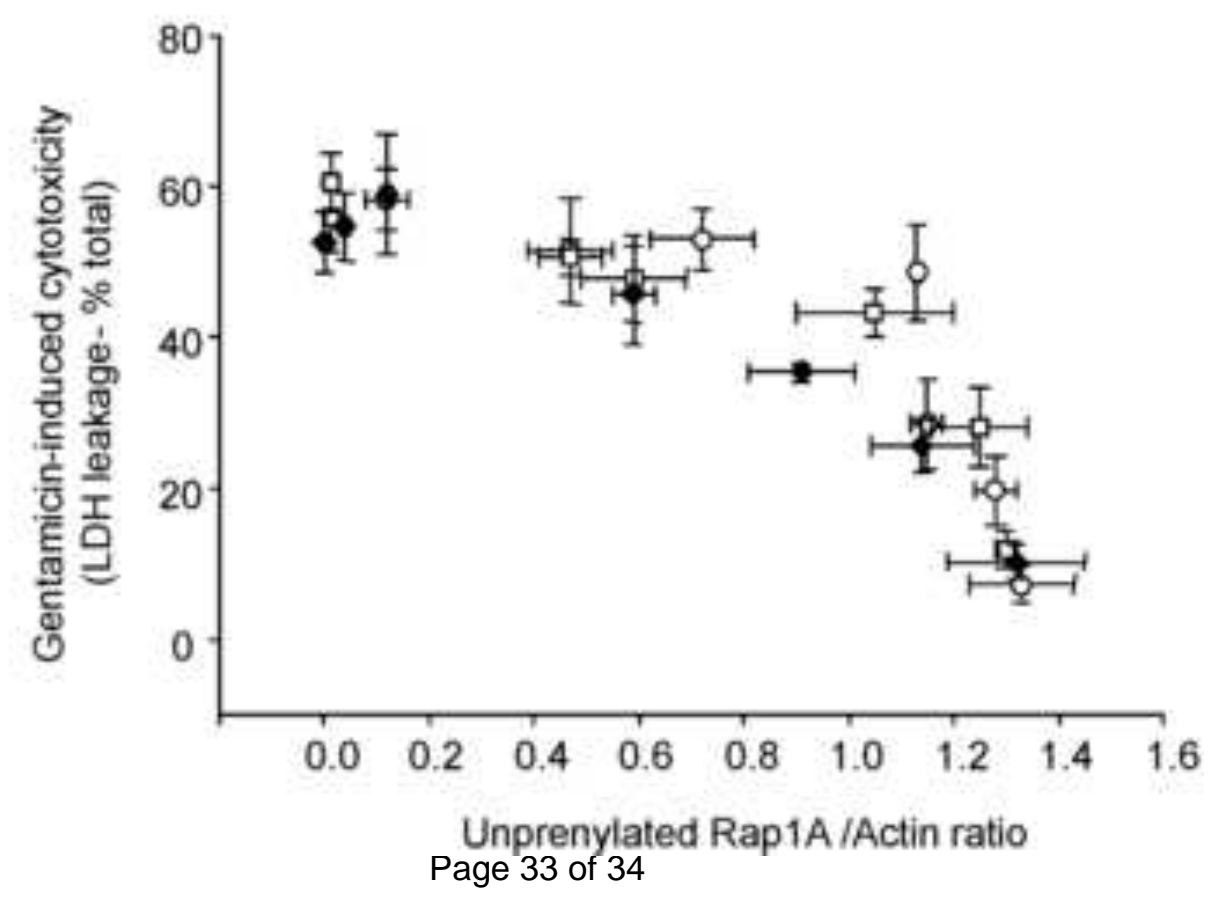


A

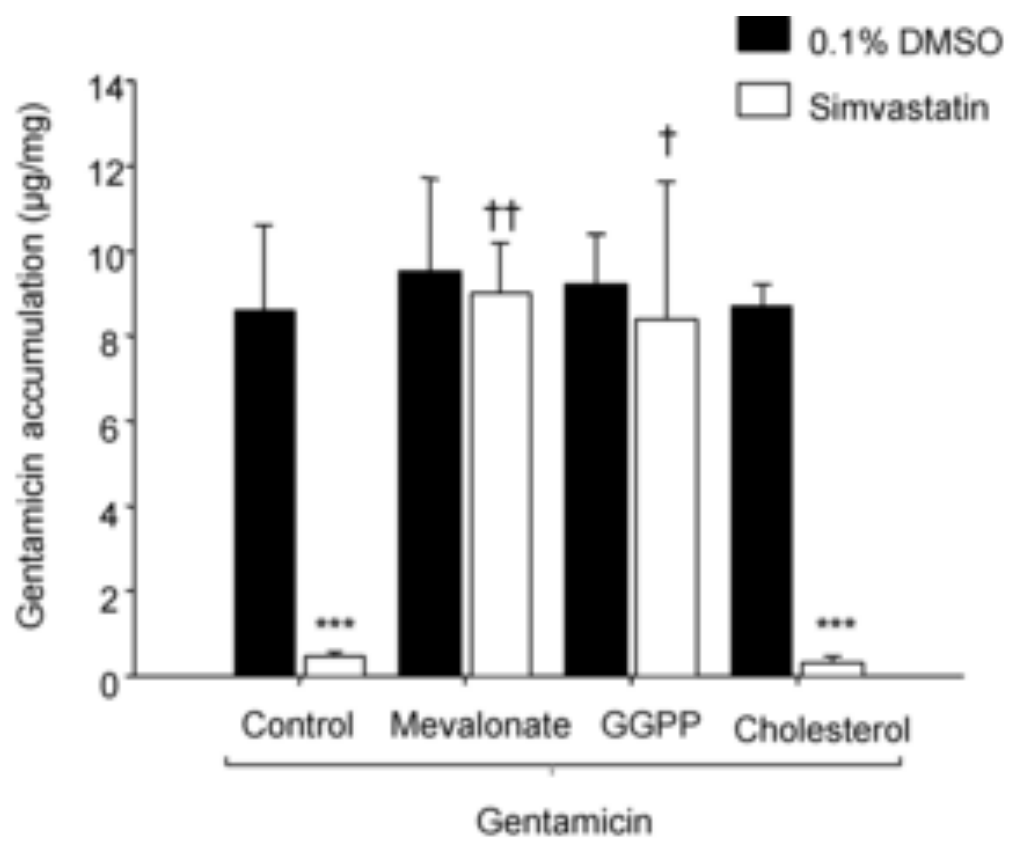

B

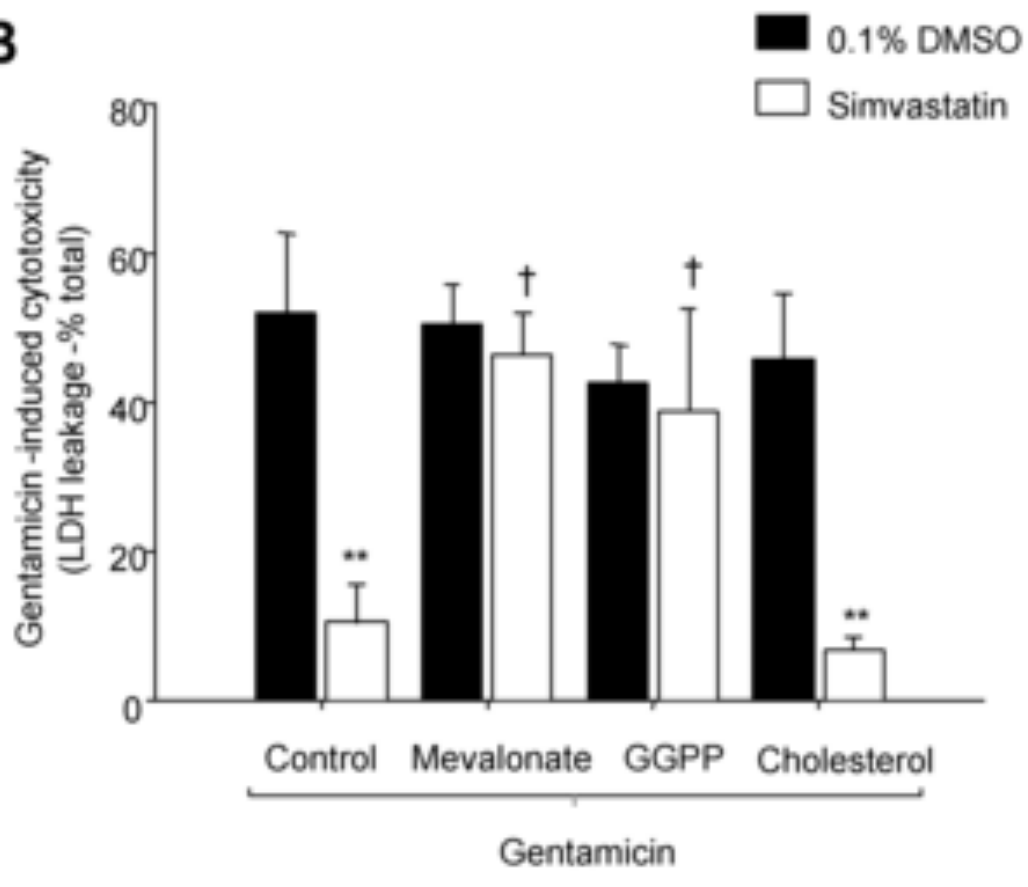

C

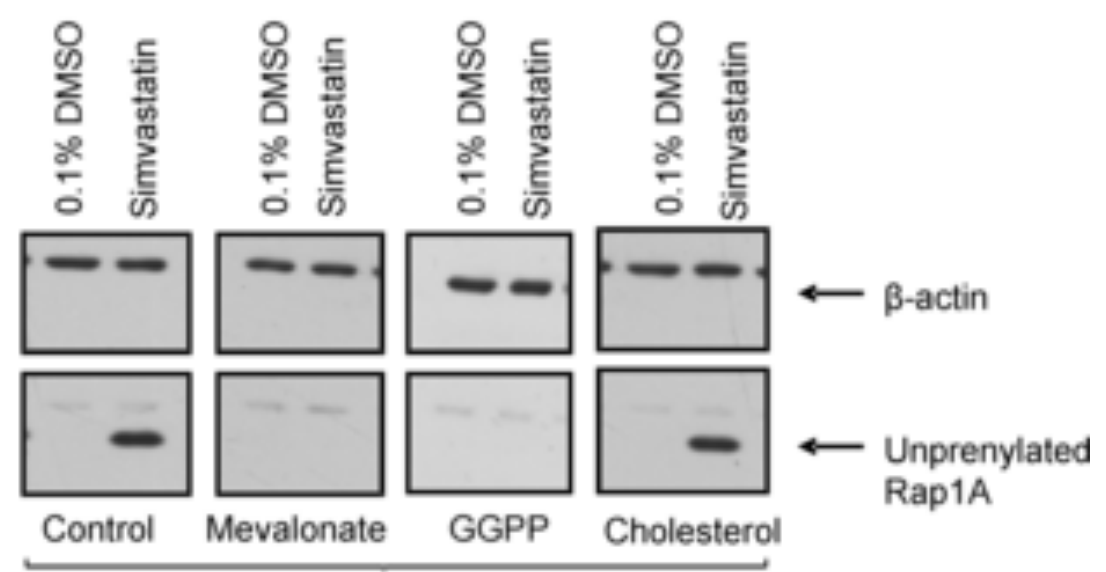

